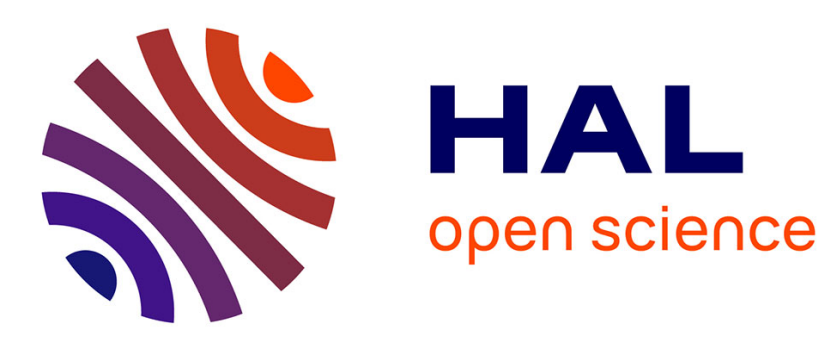

\title{
Religion, Politics, and Development: Lessons from the Lands of Islam \\ Jean-Philippe Platteau
}

\section{To cite this version:}

Jean-Philippe Platteau. Religion, Politics, and Development: Lessons from the Lands of Islam. Journal of Economic Behavior and Organization, 2008, 68 (2), pp.329. 10.1016/j.jebo.2008.06.003 . hal00630790

\section{HAL Id: hal-00630790 \\ https://hal.science/hal-00630790}

Submitted on 11 Oct 2011

HAL is a multi-disciplinary open access archive for the deposit and dissemination of scientific research documents, whether they are published or not. The documents may come from teaching and research institutions in France or abroad, or from public or private research centers.
L'archive ouverte pluridisciplinaire HAL, est destinée au dépôt et à la diffusion de documents scientifiques de niveau recherche, publiés ou non, émanant des établissements d'enseignement et de recherche français ou étrangers, des laboratoires publics ou privés. 


\section{Accepted Manuscript}

Title: Religion, Politics, and Development: Lessons from the Lands of Islam

Author: Jean-Philippe Platteau

PII:

S0167-2681(08)00124-8

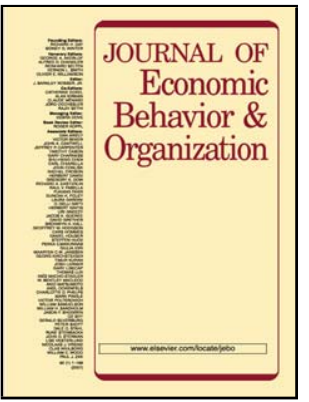

DOI: doi:10.1016/j.jebo.2008.06.003

Reference: JEBO 2221

To appear in: Journal of Economic Behavior \& Organization

Received date: $\quad$ 15-9-2006

Revised date: $\quad 3-8-2007$

Accepted date: $\quad$ 12-6-2008

Please cite this article as: Platteau, J.-P., Religion, Politics, and Development: Lessons from the Lands of Islam, Journal of Economic Behavior and Organization (2007), doi:10.1016/j.jebo.2008.06.003

This is a PDF file of an unedited manuscript that has been accepted for publication. As a service to our customers we are providing this early version of the manuscript. The manuscript will undergo copyediting, typesetting, and review of the resulting proof before it is published in its final form. Please note that during the production process errors may be discovered which could affect the content, and all legal disclaimers that apply to the journal pertain. 


\title{
RELIGION, POLITICS, AND DEVELOPMENT: LESSONS FROM THE LANDS OF ISLAM
}

\author{
Jean-Philippe Platteau*
}

October 2007

\begin{abstract}
The question as to whether religion can block economic development and institutional change, or is a purely endogenous factor, assumes particular importance today because of the rise of Islamist movements and the disappointing economic performances in the lands of Islam. This paper starts from a critical examination of the thesis of Bernard Lewis according to which the lack of separation between religion and politics creates particular difficulties on the way to modern economic growth in these lands. It will be argued that $\left(1^{\circ}\right)$ Lewis' thesis conceals the critical fact that, even when political and religious functions appear to be merged, religion is the handmaiden rather than the master of politics; $\left(2^{\circ}\right)$ the influence of religion increases when the state falls into crisis, owing to its impotence or excessive absolutism; $\left(3^{\circ}\right)$ because the Islamic frame of reference provides political rulers with a cheap default option when they are contested, they rarely undertake the much-needed reforms of the country's institutions; $\left(4^{\circ}\right)$ this way of escape is all the more attractive to contested rulers as Islamist movements, born of the internal situation as well as of the international environment, accuse them of un-Islamic behaviour; $\left(5^{\circ}\right)$ as argued by Timur Kuran, by creating an "institutional trap", the legacy of the Islamic classical system also makes institutional reforms more difficult to achieve.
\end{abstract}

Keywords: Culture, religion, Islam, Christianity, Middle East, political economics. JEL classification codes: Z12, P16, A13

\section{Centre for Research in the Economics of Development (CRED) Department of Economics University of Namur Rempart de la Vierge, 8 B-5000 Namur Belgium Email : jean-philippe.platteau@fundp.ac.be}

\footnotetext{
* I want to express my special thanks to Timur Kuran who offered me detailed and pertinent comments on a previous version of the paper. My gratitude also goes to participants in various seminars for their helpful remarks, in particular, Abhijit Banerjee, Dillip Mookherjee, Pranab Bardhan, Rohini Somanathan, and Adam Przeworki. I also thank the anonymous referees and the editor of this journal. Last but not least, I wish to express my great debt to Arab colleagues, in particular, Samir Makdisi, Ahmed Galal, Hania Abou al-Shamat, Imane Chaara and Karim Zouaoui, who have manifested a great deal of interest in the ideas treated in this paper and discussed them with me.
} 


\section{Introduction}

Of late, we have witnessed a rising preoccupation of economists about the possible role of religion (and ethnicity) in fostering or impeding economic development and growth. The main picture that emerges from a quick overview of the econometric literature aimed at identifying the main determinants of inter-country variations in long-run growth performances is the following: the null hypothesis that religious affiliation is uncorrelated with economic performances can frequently be rejected (i.e., religion matters), yet the regressions do not yield a robust pattern of coefficients with respect to particular religions, Islam included. ${ }^{1}$ On the other hand, El Badawi and Makdisi (2007) have attempted to measure the impact of the Arab dummy on political performance measured by the widely quoted Polity IV index (which provides ratings of the standards of democracy). Their conclusion is that the Arab dummy has a negative and highly significant effect even after controlling for a host of economic, social and historical variables. However, the Arab dummy ceases to be significant as a stand alone effect once it is also interacted with a variable measuring regional conflicts. The coefficient associated with the interaction term is strongly significant and suggests that in the Arab world, unlike what is observed in other parts of the world, interstate conflicts and wars tend to promote authoritarianism rather than a shift toward democracy. Religion (whether Islam or Christianity prevails) does not account for the lack of Arab democracy. Conclusions

\footnotetext{
${ }^{1}$ For example, La Porta et al. (1997, pp. 336-37) found that countries with more dominant hierarchical religions (Catholicism, Orthodox Christianity, and Islam) "have less efficient judiciaries, greater corruption, lower-quality bureaucracies, higher rates of tax evasion, lower rates of participation in civic activities and professional associations, a lower level of importance of large firms in the economy, inferior infrastructures, and higher inflation" . The study of Guiso et al. (2003) finds that Protestants, Catholics, and Hindus, unlike the Muslims, appear to be favorably disposed toward private ownership. Barro and McCleary (2003) find that Hinduism, Islam, Orthodox Christianity, and Protestantism are negatively associated with per capita income growth relative to Catholicism, while Sala-i-Martin et al. (2004), who use a larger sample, reach the opposite conclusion, that Islam is a positive rather than a negative factor for growth. Such a result is confirmed by Noland (2005) for whom the notion that Islam is inimical to growth is not supported by his data. Still more recently, Pryor (2007) comes to the conclusion that the presence of Islam has very little influence on twentythree indicators of economic and social performance.
} 
along the same line have been reached by Noland (2008) and Tessler (2002), yet not by Fish (2002). Also deserving special emphasis is the recent finding by Pryor (2007) that no special Islamic economic system can be isolated on the basis of a cluster analysis and data on fortyfour economic institutions used to define economic systems. Moreover, the share of Muslims in the population is unrelated to the presence or absence of most particular economic institutions.

Many economists who believe that cultural explanations are a priori dubious and ad hoc ways of accounting for poor growth performances will not be surprised by such an agnostic conclusion. They are prone to emphasize that, since it is possible to pick out specific aspects of almost any religion that are antithetical to economic growth, testing the impact of religion on economics is bound to be inconclusive (North 2005, 136). On the other hand, estimating the impact of culture on economic and other performances is extremely difficult because of the well-known endogeneity problem: rather than blocking development, a particular culture may evolve in a nasty direction as a result of a lack of growth. The endogeneity bias is very hard to surmount since it is practically impossible to find variables that influence culture without affecting growth performances in one way or another. Little can therefore be learned about causal effects from cross-sectional results. However another, equally serious problem plagues cross-country econometric studies, and it is especially evident in the case of the religious component of a cultural endowment. Owing to the paucity of data available, the measurement and aggregation of religious affiliations that form a highly delicate part of the whole exercise are typically done in an extremely crude manner. ${ }^{2}$

Because of these problems and because the reciprocal effects between culture and development carry long time lags, more reliable lessons can presumably be learned from a

\footnotetext{
${ }^{2}$ Thus, how do we have to interpret the effect of religion when denominations are aggregated into such broad categories as Protestantism or Islam, thereby ignoring the multiple and subtle subdivisions and sects into which they have split over the course of their history? Moreover, two persons who declare themselves Christian Catholic or Muslims may mean different things and behave according to different interpretations of the religious doctrine invoked.
} 
historical foray of the issue than from cross-country regressions. The fruitfulness of the historical approach is illustrated in the present paper with specific reference to the case of Islam. Such a choice is justified by the fact that the Arab world has gone through a prolonged period of low growth and democracy deficit while witnessing the ominous rise of radical Islamist movements. We are interested in knowing whether and to what extent this predicament can be attributed to intrinsic features of Islam and what the origins of the Islamist movements are.

The inquiry below rests on a critical examination of the elegant and attractive thesis recently put forward by Bernard Lewis in his book What Went Wrong? (2002). In a nutshell, a specific feature of the Islamic world (the lack of separation between religion and politics) creates particular difficulties on the way to modern economic growth (see Section 2). What is argued in the paper is the following: $\left(1^{\circ}\right)$ Lewis' thesis conceals the critical fact that, even when political and religious functions appear to be merged, religion is the handmaiden rather than the master of politics; $\left(2^{\circ}\right)$ the influence of religion increases when the state falls into crisis, owing to its impotence or excessive absolutism (Section 3$) ;\left(3^{\circ}\right)$ because no vertical chain of command exists that can impose a uniform orthodoxy in the lands of Islam, the Islamic frame of reference provides political rulers with a cheap default option when they are contested, as a result of which they rarely undertake the much-needed reforms of the country's institutions (Section 4$) ;\left(4^{\circ}\right)$ this way of escape is all the more attractive to contested rulers as Islamist movements, born of the internal situation as well as of the international environment, accuse them of un-Islamic behaviour: a serious risk of obscurantist deadlock is thereby created; $\left(5^{\circ}\right)$ as argued by Timur Kuran, by creating an "institutional trap", the legacy of the Islamic classical system also makes institutional reforms more difficult to achieve (Section 5). 
In conclusion (Section 6), we require a dynamic framework to understand satisfactorily the path-dependent trajectory followed by Islamic countries. For long-term progress to be possible, the escape valve of Islamist outbidding ought to be made more costly for inadequate rulers. However, such an outcome can happen only if people are able to challenge their leaders with the help of secular-rationalistic systems of ideas, which requires, in turn, that behavioural and institutional changes have taken place on the levels of the economy and that merchants dare break out of their alliance with religious authorities where it has been traditionally strong. If an "institutional trap" exists, such changes will be especially difficult to achieve. Bringing into the picture the complex interaction and feedback effects existing between culture and institutional change enables us to draw an insightful contrast between the virtuous development trajectory of Western Europe in modern times and the nasty path trodden by the lands of Islam during the same period.

\section{The challenging thesis of Bernard Lewis}

\subsection{A background view of Western Europe as successful path-dependent development}

Careful examination of the historical evidence pertaining to Western Europe suggests that the relationship between culture and institutions is dialectical and involves feedback effects along a complex dynamic path. Contrary to the well-known thesis of Max Weber (1930), for whom the Protestant Reformation was a critical moment conducive to modern capitalist growth in Europe, and to the more recent view of Jonathan Israel (2001), for whom it is the Early Enlightenment (1680-1750) that played that role, it seems that systems of ideas have largely adjusted to changes occurring on the level of the economy and the polity. It would be difficult to explain otherwise how dynamic Catholic merchants could operate in 
prosperous North Italian and Flemish cities even before the advent of Protestantism ${ }^{3}$ and how such important steps as the Petition of Rights (1628), whereby all Englishmen were granted a set of rights protected by a law enacted by Parliament, or the abolishing of the Star Chamber (1641) and the concomitant ruling requiring that all cases involving property be tried at common law courts, or the Glorious Revolution (1688), which initiated the era of parliamentary supremacy, implying that the Crown could no longer claim to be above the law, could take place so early in the history of modern England (North and Weingast 1989). ${ }^{4}$

A valid point can nevertheless be made that by articulating powerful ideas that questioned the existing socio-political order (including the old hierarchy of studies) and shook the mental world of the west along rationalistic and secular lines, the New Philosophes gave an impetus to new economic and political changes that were to have a profound impact on contemporary European society. In other words, Western Europe was placed on a virtuous path-dependent trajectory that triggered self-reinforcing modernizing changes on multiple levels. It bears emphasis that ideological and intellectual transformations in Europe were much more gradual than usually thought. In the words of Joseph Schumpeter (1954, pp. 80$82)$,

There is little if anything to the saga of a new light that had flashed upon the world and was bitterly fought by the powers of darkness, or of a new spirit of free inquiry that the henchmen of hidebound authoritarianism vainly tried to smother... the authority of the

\footnotetext{
${ }^{3}$ Migration actually provided a direct link between the presence of entrepreneurship in Catholic and Protestant cities. During the $16^{\text {th }}$ and $17^{\text {th }}$ centuries in the Low Countries, dynamic people, merchants in particular, fled from southern areas (Antwerp, most notably) to northern Calvinist-controlled areas in order to escape the oppressive climate of the counter-Reformation. Many of these migrants later converted to Protestantism. Rather than being the driving force of capitalism, the rise of Protestantism seems to have been induced by emerging capitalist entrepreneurship: dynamic individuals did not become merchants or capitalist entrepreneurs because of their (Protestant) beliefs, but instead, they adopted a religion that was compatible with their economic aspirations and their interests. Interestingly, Tawney (1926) himself was more inclined than Weber to reckon that the Reformation stimulated a movement already under way; it is striking that the more highly developed districts were those which gave most support to the Reformation, finding its creed more suitable to aggressive and progressive ways of life (Higgins 1968, pp. 163-64, Pettegree 2003, p.68).

${ }^{4}$ Maxime Rodinson (1966) correctly points out that "Weber describes substantial features of higher rationality existing in Europe only in the modern age, the age when modern capitalism was already predominant, so that it is impossible to prove that these features were not created by the economic regime they accompany" (quoted from the English translation 2007, p. 157).
} 
Church was not the absolute bar to free research that it has been made out to be... The society of the feudal ages contained all the germs of the society of the capitalist age. These germs developed by slow degrees, each step teaching its lesson and producing another increment of capitalist methods and of capitalist 'spirit'... [Weber] set out to find an explanation for a process which sufficient attention to historical detail renders selfexplanatory. ${ }^{5}$

Moreover, it is too easily forgotten that the Reformation eventually gave rise to enormous confessional tensions and an acute competition among rival religious denominations or sects, and these actually resulted in an abrupt raising of moral standards imposed by austere moralizing creeds and an extension of the sacred into all areas of life. At least, this was true for a minority of enthusiasts, but more tolerant Christians found it difficult to resist them openly (Briggs 1999, pp. 174-76, 181, 191; see also Koenigsberger et al. 1989, pp. 222-25, 351-54). English Puritans, or Dutch Protestant soldiers, displayed attitudes of moral rigour and intolerance (including rejection of every representation of God in a church, and reaction against cults of saints in an attempt to purify the house of God from intrusive idols) that were a direct consequence of the Protestants' paramount objective, namely to return to the pristine practice of the primitive Church (Toynbee 1972, pp. 475-76, Strong 2007). In some cases these attitudes, which strikingly evoke present-day postures by Islamists $^{6}$, led to the worst forms of persecution as attested by the massacres of Anabaptists in Germany and the Netherlands. In the words of Fernand Braudel (1995, p. 353), "Inaugurated under the banner of liberty and revolt, the Reformation soon lapsed into the same degree of

\footnotetext{
${ }^{5}$ For Schumpeter, interestingly, the conflict was political in nature: "The laical intellectuals, Catholics no less than Protestants, were often opposed to the Church as a political power, and political opposition against a church very easily turns into heresy" (p. 82).

6 "Puritans demanded a new moral discipline, not only of themselves, but of the whole community as well. They were opposed to many folk customs as well as amusements such as May-poles, morris dancing, ballad singing and plays. They wanted a clear line to separate the sacred from the profane, calling for an end to Sabbath breaking, elaborate funerals, and the use of churchyards as places for public gatherings and festivities... they wanted to stamp out semi-magic rituals..." (Koenigsberger et al. 1989, p. 354).
} 
intransigence of which it accused its enemy. It built a structure as rigid as medieval Catholicism". 7

Also supporting the idea that changes were slow, especially in the sphere of ideas and beliefs, is the "durability of conventional religious beliefs" and the fact that almost all the major intellectual figures who contributed to the new philosophical and scientific revolution did so "in a distinctly religious spirit" (Briggs 1999, pp. 171, 204). In the words of Robin Briggs: "Religion still provided the framework within which everything was set, so that there appeared to be little difficulty in absorbing new intellectual trends within Christian doctrine" (p. 205). Science and religion were not seen as being in direct conflict inasmuch as "knowledge of the natural world was also knowledge about the divine purpose" (p. 171; see also Collins and Taylor 2006, pp. 155-59). The understanding of the world in rational, analytical and quasi-scientific terms remained the attribute of a small elite until well into the $19^{\text {th }}$ century, the outlook of the majority remaining traditional and largely rooted in religion (Anderson 2003, p. 381).

What is remarkable in the modern history of the most advanced parts of Western Europe, however, is that, although necessarily slow and progressive, the shift towards rationalization and secularization was pursued in a more or less continuous and sustained manner. This provides a striking contrast to Russia, for example, where a long autocratic political tradition dating back to the to the $15^{\text {th }}$ century (when the Muscovy princes began to dominate the country at the expense of the more liberal rulers of Kiev and Novgorod, two prosperous cities thriving at the edge of the Western European merchant-capitalist world ${ }^{8}$ )

\footnotetext{
${ }^{7}$ Robert Briggs (pp. 182-83) writes in the same vein that, "despite its initial appeal to the laity, Protestantism rapidly evolved into a new and highly demanding form of clericalism, whose rigid doctrines and intense moralism were ill-suited to win general support".

${ }^{8}$ See, for example, Pipes (1995, p. 105), Raeff (1984, p. 10), Riasanovsky (1993, pp. 183-95).
} 
prevented the Enlightenment ideas to strike deep roots, even when they were systematically imported during the reign of Catherine the Great. $^{9}$

\subsection{A condensed view of 'What Went Wrong?'}

In the light of the above lessons from the Western European experience, the thesis expounded by Bernard Lewis in his New York Times Bestseller What Went Wrong? (2002) appears all the more challenging. What Lewis contends, indeed, is that Islam is a genuine obstacle to development and that it differs radically from Christianity. In other words, religion is not necessarily an obstacle to development, but in the specific case of Islam, it appears to be so.

Lewis' argument rests on the contention that, in contrast to Christianity, the separation between politics and religion, God and Caesar, Church and State, spiritual and temporal authority, has never really occurred in the Islamic world. As a consequence, individual freedom, social pluralism, civil society, and representative government were prevented from evolving in Muslim societies. The reason for the lack of separation between the religious and the political spheres in the Muslim world is argued to be historical: the Prophet Muhammed became the political leader of his own city (Medina), causing a complete merging of religion and politics and suppressing any move toward building a religious establishment. In the words of Ali Shari'ati, "the Prophet of Islam was the only one who simultaneously carried the sword of Caesar in his hand and the heart of Jesus in his chest" (1986, p. 23, quoted from Hassan and Kivimäki 2005, p. 125). Naturally, the succeeding caliphs held both temporal and spiritual powers.

\footnotetext{
${ }^{9}$ During the second half of the $18^{\text {th }}$ century, the empress Catherine reinforced her autocratic authority, denied the necessity of providing legal guarantees to protect subject people, and passed repressive laws (such as the 1765 law that forbade peasants to make complaints against their masters but granted to the gentry the right to punish their serfs by exiling them to Siberia) while professing hypocritically to adhere to the liberal philosophy of the French Encyclopedists (Walicki 1979, pp. 2-8).
} 
The first Christians built up a Church structure to defend themselves against a state that oppressed them (until Constantine converted to Christianity) and adhered to the principle "render unto God that which is God's and unto Caesar that which is Caesar's" According to an authoritative voice, the separation between the state and the Church in Western Christianity did not seriously start until the Gregorian reforms during the $11^{\text {th }}$ century. These reforms, initially intended to shield the Roman papacy from the political ambitions of the German emperor, ended up causing "a genuine separation between the clergy and the laity, between God and Caesar, between the pope and the emperor" (Le Goff 2003, p. 86). The critical point is that Muslims had no such need to isolate the religious sphere from the political one. In Islam, there is no ecclesiastical body, nor is there any vertical chain of command to direct the believers (except in Iran where the Shi'a tradition prevails and a clerical establishment that has been expanded after Khomeini's revolution exists): Muslim believers refer directly to God and its law on earth, the shari'a. "Since the state was Islamic, and was indeed created as an instrument of Islam by its founder, there was no need for any separate religious institution. The state was the church, the church was the state, and God was head of both, with the Prophet as his representative on earth... From the beginning, Christians were taught, both by precept and practice, to distinguish between God and Caesar and between the different duties owed to each of the two. Muslims received no such instruction" (Lewis 2002, pp. 113, 115).

According to the same logic, there is no such thing as a laity in the lands of Islam:

The idea that any group of persons, any kind of activities, any part of human life is in any sense outside the scope of religious law and jurisdiction is alien to Muslim thought. There is, for example, no distinction between canon law and civil law, between the law of the church and the law of the state, crucial in Christian history. There is only a single law, the shari'a, accepted by Muslims as of divine origin and regulating all aspects of human life: civil, commercial, criminal, constitutional, as well as matters more specifically concerned with religion in the limited, Christian sense of the word... One may even say that there is no orthodoxy and heresy, if one understands these terms in the Christian sense, as correct or incorrect belief defined as such by duly constituted religious authority...Even the major division within Islam, between Sunnis and Shi'a, arose over an historical conflict about 
the political leadership of the community, not over any question of doctrine. (Lewis 2002, pp. 111-12)

The only vital division in Islam is between sectarian and apostate: "Apostasy was a crime as well as a sin, and the apostate was damned both in this world and the next. His crime was treason -desertion and betrayal of the community to which he belonged, and to which he owed loyalty. His life and property were forfeit. He was a dead limb to be excised" (Lewis 1995, p. 229). For the rest, "The absence of a single, imposed, dogmatic orthodoxy in Islam was due not to an omission but to a rejection -the rejection of something that was felt by Sunni Muslims to be alien to the genius of their faith and dangerous to the interests of their community... The profession of Islam... is that God is one and Muhammad is his Prophet. The rest is detail". In other words, tolerance must be extended to all those who "reach the required minimum of belief', while intolerance is required toward all those who deny the unity or existence of God, the atheists and polytheists ((Lewis, 1995, pp. 229-30).

The sovereign is just the "shadow of God on earth", in charge of enforcing yet not interpreting the words of God. There is actually no concept of nation or people in the Islamic world, only that of the community of believers (the umma) that transcends physical boundaries. This is best expressed by Hassan Al-Banna (more about him later) when he states, "Islam is a comprehensive system which deals with all spheres of life. It is a country and a home or a country and a nation" (Al-Banna 1996, p. 7, quoted from Hassan and Kivimäki, p. 127). ${ }^{10}$

To sum up, the difference between Christianity and Islam is so radical that it reflects a clash of cultures and civilizations: to the Western perception of the separation of religion from political life and the assertion of individual rights, the Muslims oppose an all-encompassing view of the divine law that implies the amalgamation of religion and politics and the

\footnotetext{
${ }^{10}$ It is thus revealing that the Palestinian Islamist movement, Hamas has been severely blamed by Osama bin Laden and his Al-qaeda movement for having agreed to run for a national election (January 2006). Following its victory, Hamas has ruled over a national territory instead of fighting on behalf of the whole world Muslim community.
} 
recognition of collective rights for all the Muslim faithful. From there, it is just a short step to contend that "Islam and democracy are antithetical" since obedience to religious tenets is inherent in Islamic religious doctrine (Lewis 1993, p. 91; see also Miller 1993, pp. 45-51, Kepel 1994, p. 194, Pipes 1995, p. 192). As stressed by Karl Marx, a modern market economy cannot develop in the absence of a civil society understood as an autonomous sphere of economic activity, unimpeded by political and religious restrictions (see Avineri, 1968, pp. 154-55). For Lewis, it is precisely this sort of emancipation that is prevented from occurring in the lands of Islam.

\subsection{A clarification}

From Lewis' account, it is evident that the distinction between the Muslim and the Christian civilizations, or 'institutional complexes' (Greif, 2006), dates back to the critical moments of the foundation of the faiths: the rise of Christianity within the Roman Empire on the one hand, and the rise of Muhammad in a context where he had to construct a political, economic and social order on the other hand. This idea has been forcefully restated by Avner Greif who even establishes a parallel between Islam and Judaism in this regard:

Because the Roman Empire had a unified code of law and a rather effective legal system, Christianity did not have to provide a code of law governing everyday life in creating communities of believers. Christianity developed as a religion of orthodoxy and proper beliefs; in earthly matters, Christians followed Roman law and later other secular laws. ... Islam rose through a very different process, in which Muhammad established both a religion and a political, economic, and social unit. Islam therefore had to provide, and emphasize the obligation of adherents to follow, the Islamic code of law, the Shari'a. Like Judaism, therefore, Islam is a religion that regulates its adherents' behaviour in their everyday, economic, political, and social life. (Greif 2006, p. 206, see also Kuran 2004b).

As Lewis is aware, the behaviour of Muslims could not be governed only by reference to texts, however sacred, elaborated during the times of the founder of the faith: the shari'a cannot be reduced to the Qur'an. As a matter of fact, the words of the Qur'an were not deemed by Muslim thinkers to be a sufficient guide for an empire stretching from Spain to 
Central Asia, and one of the strengths of Islam during the times of conquest when it came into contact with peoples of diverse local cultures and religions was the recognition that different manifestations of popular piety would have to be tolerated within the umma. ${ }^{11}$

During the period running from the $8^{\text {th }}$ to the $10^{\text {th }}$ centuries, it became increasingly recognized that a uniform code of conduct defining what is absolutely true and eternal could be devised and enforced only by complementing the Qur'an with three other sources of law that would come to form the shari'a. These supplementary sources were the tradition of the Prophet (known as the sunnah), which comprises his sayings and actions (the hadith); analogy based on precedents; and the consensus of the community (ijma), as determined by the decisions of the ulema who are the jurists-cum-theologians in charge of interpreting the intent of God's revelations and assessing "the legality of the actions of individuals on the basis of their compliance with God's commands". The ulema establishment comprises the individuals trained in the Islamic law, that is, the scholars who compilated the shari'a, the judges who applied it in the Islamic courts (the qadis), the legal experts who advised the judges (the muftis), and the teachers who educate the Muslim community (the mudarris) (Cleveland 2004, pp. 27-28, Gleave and Kermeli 1997).

The question then arises as to whether the ulema fulfill a function more or less equivalent to the ecclesiastical structure in the Christian world where it has the authority to enforce uniform interpretation of God's message. Admitting such an equivalence would obviously undermine Lewis' argument that, unlike what is observed among Christians, Muslim believers directly relate to God and just a 'minimum of belief' (to recognize the unity or existence of God) is required of them. The crucial importance of this point will become more evident later.

\footnotetext{
${ }^{11}$ To some extent, this was also true of Christianity. It is thus easy to find in the rituals of the Catholic Church erstwhile pagan customs borrowed from the Celtic culture (feasts, sacred places, sacred women figures, etc).
} 
Leaving aside the particular case of Iran, ${ }^{12}$ Lewis is essentially correct in saying that no priesthood exists in the Islamic world, if we mean that there are no human intermediaries between the individual believer and God. At the same time, the ulema were able to provide a measure of unity to law and doctrine by codifying and transmitting religious knowledge, and they have always exercised substantial control and influence over how Muslims interpret Islam. Moreover, the madrasas, those schools of instruction created in Baghdad in the $11^{\text {th }}$ century, helped a great deal to maintain a certain unity in the Islamic scholarly tradition (Makdisi 1981, Berkey 1992 and 2007, Kuran 1997, p. 52, Goffman 2002, p. 72, Cleveland 2004, pp. 28-29).

Bearing the above qualification in mind, a significant difference exists between Islam and Christianity: in spite of the presence of the ulema, Islam leaves a rather ample margin of freedom for the interpretation of the Qur'an. This is because rules tend to be scattered throughout the works of the ulema who, moreover, do not form a religious establishment that can declare by fiat which is the correct interpretation of the Qur'an, and because no central power structure resembling the Vatican (with its ability to excommunicate) has ever existed to lead the Muslim world community except for first Caliphate. Muslim believers, therefore, appear to be both more and less constrained than their Christian counterparts. They are more constrained insofar as all aspects of their lives fall under the purview of the shar'ia, yet they are less constrained insofar as, in strictly religious matters, they are generally not subject to precise and rigid rules.

Furthermore, Islamic legal practice was defined by a combined interpretation of the shari'a law and the classic sources of Islamic jurisprudence, on the one hand, and local customary law, on the other hand. The latter was called when the former failed to provide

\footnotetext{
${ }^{12}$ There is ample ground to regard the djomehs imams as abbeys, the hodjatoleslams as bishops, the ayatollahs as archbishops, the grand ayatollahs as cardinals, and the marjaya tabligh as a sort of patriarch which the khomeynist revolution has tended to transform into a unitary Shi' ite papacy (Adler 2005 , p. 122, footnote). In fact, all Shi'a sects retain relatively defined clerical hierarchies, and the Jaafaris, the dominant branch of Shi' ism, sustain a loosely church-like clergy.
} 
answers or simply when the 'law of the land' prevailed. By its very nature, Islamic legal practice was therefore 'a cultural hybrid', and legal service providers had to know local cultural norms in addition to Islamic codes (Lydon 2007, p. 19). This applies especially well to the Ottoman state, which drew upon all four schools of Islamic law in its law-making, institutionalized various systems of sufism (Islamic mysticism) within its urban communities and military organizations, and did not hesitate to use customary law in order to placate its disparate population of Christians, Jews, and followers of different schools within Sunni Islam (Goffman 2002, p. 73).

In the lands of Islam, religious dignitaries (e.g., the imams) may indulge in preaching and teaching the faithful in the numerous existing madrasas and mosques, and this typically means that the messages conveyed can vary considerably from one place to another. In Pakistan, for example, the content of the syllabi differs according to the madrasa, and the militant and sectarian teaching is transmitted orally and depends very much on the political affiliation and personality of the preacher (Piquard 1999, p. 76). A major implication can be drawn from the foregoing discussion, "the decision to oppose the state on the grounds that it is insufficiently Islamic belongs to anyone who wishes to exercise it" (Zakaria 2003, pp. 124-25, 144), which provides an important link to the main argument developed in the subsequent sections of the paper. Since Muslims can turn to preachers of their own choice, and these preachers are not subject to the rigid ruling of a priestly caste acting as the representative of God, could not religion be manipulated by politics? Such possibility is normally precluded in Lewis' scheme of analysis, where states and political authorities appear to be largely subsumed or merged into the religious realm. ${ }^{13}$

\footnotetext{
${ }^{13}$ Oddly enough, Lewis points out that, in Islam, religious agents never really succeeded in imposing ecclesiastical constraints on political and military rulers. He also describes as rare the attempts made by Muslim sovereigns to bring religion under control (Lewis 2002, pp. 135-36). One wonders how the first statement can be reconciled with his central thesis about the lack of separation between religion and politics. As for the second statement, it is questionable in the light of the evidence adduced below that political rulers often succeeded in instrumentalizing religion in the lands of Islam. Whether this
} 


\section{The role of politics and the instrumentalization of Islam}

\subsection{First insights drawn from the early history of Islam}

A good starting point to explore the relationship between religion and politics in the lands of Islam and to illustrate the point that religion is easily manipulated by all political actors is the history of the first centuries of Islamic rule. As attested from the very beginning by the murders of three of the four caliphes who succeeded Muhammad, the history of Islam is full of violent confrontations between various factions vying for power and adhering to different interpretations of the Qur'an, each claiming legitimacy for its own version of inheritance from the Prophet. During the times of Muhammad, there was already continuous competition and warfare not only between the merchant dynasties of the cities and the Bedouin coming from a rugged desert terrain, but also within each of these groups. Under the first caliph (Abou Bakr), the converts from Medina claimed that political power should be made accessible to all Muslims whereas the caliph argued contrariwise that it should remain the exclusive preserve of the original group of believers, meaning the members of the Quraysh clan (Muhammad's tribe). ${ }^{14}$ Under the third caliph (Othman), the best state positions were earmarked for his own clan, and the first Ummayyad caliph (who transferred the capital city from Mecca to Damascus in 657) won power after having defeated Ali, the fourth caliph and the religious Shi'a hero.

Rather than originating in a doctrinal conflict, Shi'ism thus began as a movement of support for the leadership of certain Arab candidates in the caliphate, in opposition to the hegemony of Syrian Arab tribes ruling from Damascus. ${ }^{15}$ A complete dissociation between

amounts to saying that they succeeded in bringing it under control is an open question that is largely semantic.

${ }^{14}$ This requirement was to be reasserted in the most famous theoretical exposition and defence of the caliphate, that of al-Mawardi (d. 1058) (Hourani 1991, p. 142).

${ }^{15}$ Iraqi Shi'ism (the movement supporting Ali's descendants who were expected to rule from Kufa in Iraq) united with the Khurasani tribes from the Iranian northeastern highlands and with the 
politics and religion ensued, and the function of the caliphate was emptied of all its sacred content. The merchant aristocracy of Mecca, in particular, actively fought against prophetic preaching. For this reason, the seizure of power by the Meccan clan of the Ummayyads may be seen as an usurpation. The Abbasids (from Bagdad), who overthrew the Ummayyads, attempted to revitalize the sacred function of the caliphate but did not quite succeed. As early as the middle of the $10^{\text {th }}$ century, the institution declined after less than two centuries of glory (see Meddeb 2002, p. 96).

The central lesson to draw from the above cursory account is the following: what appear at first sight as conflicts between various religious factions or interpretations of the faith often conceal more down-to-earth struggles between different clans or tribes over access to political power and the economic privileges that go with it. Religion was a legitimizing instrument in the hands of established rulers in need of popular support or in those of contending political rulers. Initiating a long tradition in which political power is exercised by military leaders who dressed themselves as emirs, Baybars, the great Mameluk ruler, used the prestigious figure of the caliph to sanctify his own worldly glory, in the same way that Friedrich II (1194-1250), a Hohenstaufen, obtained the title of king of Jerusalem to enhance his powers in Europe (Meddeb 2002, Chaps 16-17). ${ }^{16}$

underground Abbasid movement whose claim to rule also originated in Muhammad's broad tribal family. Upon overthrowing the Ummayyads, the Abbasids pushed away their allies to build a broad base of Islamic clerical wisdom (Makiya 1989, p. 213). As a result, the Abbasid Caliphs coexisted with increasing difficulty with the Shi'ite imams (all direct descendants of the Prophet via Fatima and of Ali, the fourth caliph) whom they controlled from close quarters and often ended up assassinating. The only real attempt at reconciliation occurred when Al Mamoûn allied himself with the progressive eighth imam, Ali Reza, and tried to propagate the rationalist doctrine of the Mutazilis (according to which truth can be reached by using reason on what is given in the Qur'an) as the official philosophy of the state. He went so far as planning to make Ali Reza his successor. Following a revolt of part of his army in Baghdad, Al Mamoûn was compelled to revise his plan and most likely ordered the poisoning of Ali Reza. As for the Mutazilis thinkers, they gradually ceased to be important within the emerging Sunni community, but their influence remained strong in the Shi'ite schools of thought as they developed from the $11^{\text {th }}$ century (Adler 2005, p. 110, Hourani 1991, pp. 63-64).

${ }^{16}$ As we shall see later, to assert and to maintain their monopoly over the right to rule, the Ottomans also laid claim to several honorary titles that had spiritual significance among the subjects. 
This conclusion fits well with what we know not only about Arab countries, but also about other lands of Islam. The example of Mali is instructive in this regard. An ambitious warlord, Askia Mohamed, became one of the most renowned rulers of the Songhaï Empire. To succeed in his military campaigns, he went to Mecca in 1496 and, upon his return, he took the title of "Calife of the Soudan". Using his new Islamic credentials, he embarked upon a jîhad and quickly displaced political contenders (Davidson 1991, p. 106, Milet 2005, pp. 41 42). In fact, the history of the Songhai empire of Gao (1528-1591) was one of continuous struggle between two political groups, "one with colours that were Songhai, pagan and nationalist, and the other proclaiming a Mali-type Muslim universalism" (Fage and Tordoff 1995, p. 79). ${ }^{17}$

In early $17^{\text {th }}$ century, the Massassi, a people of mixed Soninke and Fulani descent, "had Muslim clerics in their entourages and, when it suited their interests, acted in Islamic ways", yet, "their political actions were in no way Islamic; they were concerned with converting the clan and age-grade structures of traditional Bambara society into associations of serfs and clients subordinate to their will as war-leaders" (Fage and Tordoff 1995, p. 189). ${ }^{18}$ Two centuries later, El Hadj Oumar Tall, at the age of 23 , went on pilgrimage to Mecca and came back with the title of "Calife of the brotherhood Tidjaniya for the Soudan". In the Fouta-Djalon (in today's Guinea) where he took temporary refuge, he founded a zaoüa, which was successful in attracting numerous young Toucouleurs willing to learn the new religious doctrine and to embark on a jîhad that ended with the destruction of the Muslim

\footnotetext{
${ }^{17}$ The renowned Sunni Ali, who initiated the systematic conquest of their neighbours by the Songhai (1464), tended to rely on the support of farmers rather than city dwellers and merchants. As a result, he was "much more a potent force in Songhai traditional religion than a good Muslim" (Davidson, 1991, p. 105).

${ }^{18}$ This is about the same story as that of the marabouts of the Sine-Saloum (Senegal), who came to play in their Mouride sodality the dual roles of religious leaders and dynamic patrons exercising authority over highly submissive disciples-cum-clients (the talibé) (Cruise O'Brien 1971 and 1975, Boone 1992, pp. 106-9).
} 
kingdoms of the Khasso and the Masina (Fage and Tordoff 1995, pp. 209-11, Milet 2005, p. $50)$.

\subsection{The dominant politico-religious equilibrium in the lands of Islam}

As the preceding account suggests, and opposed to what Lewis contends, political rulers tend to have the upper hand in their dealings with religious authorities in the lands of Islam. The principle of non-attachment to worldly affairs seems to have prevailed throughout most of the history of these countries. According to Albert Hourani (1991, pp. 143-45, 458), if rulers had to negotiate with the ulema, and if their authority was legitimate only if used to maintain the shari' $a$, and therefore "the fabrics of virtuous and civilized life" (a caliph's main duty was to watch over the faith), a powerful tradition among the ulema (among both the Sunni and the Shi'ite Muslims) provided that "they should keep their distance from the rulers of the world". This implied that they ought to avoid linking themselves too closely with the government of the world while preserving their access to the rulers and their influence upon them. Even if the ruler was unjust or impious, "it was generally accepted that he should still be obeyed, for any kind of order was better than anarchy". Hourani refers to the traditionalist and most influential philosopher Al-Ghazali (1058-1111) who wrote that "the tyranny of a sultan for a hundred years causes less damage than one year's tyranny exercised by the subjects against one another". Therefore, Hourani comments, "Revolt was justified only against a ruler who clearly went against a command of God or His prophet": anarchy is the most abhorred state and, to prevent it from emerging, despotism is justified (p. 144). Note carefully that this tradition developed in spite of the professed aim of Islam to establish a righteous world order and to provide guarantees against despotic rule.

The story of precolonial Morocco, as reported by Mohamed el Mansour (1979), is illustrative of the sort of politico-religious equilibrium referred to by Hourani. The rule of 
Moroccan sultans was generally strong, reflected in authoritarian and centralizing policies. At the heart of the prevailing equilibrium lay an institution called the hurm, a sacred place or sanctuary in which everyone living was considered to be holy and all forms of violence were prohibited. ${ }^{19}$ As a shelter for those seeking God's protection, it was inviolable, implying that the sultan's men could not invest it and any fugitive was immune from pursuit. Each hurm had well-defined limits, was the property of a religious group, and carried a number of economic and social privileges (tax exemptions, in particular) in addition to moral benefits.

The granting by the sultans of considerable privileges to those holding the sanctuaries actually reflected a power distribution between the temporal authorities and the religious groups. In some sense, the hurm served as a buffer institution between the central government and the various loci of religious power since the sovereign was in no position to monopolize religious legitimacy in spite of his special relationship to God under Islam (el Mansour, pp. 69-70), yet cooperation between political rulers and religious authorities and groups was the dominant pattern observed in precolonial Morocco. When the sultan's power was contested and when the use of sheer force was rather ineffective in curbing rebellious movements (such as in his relations with the powerful urban community of Fez), the sultan co-opted the local religious elite and granted them privileges in the form of donations, tax exemptions, decrees of distinction, land grants, and the right of sanctuary. Potential opponents were thus confined to the religious field and persuaded that "spiritual leadership of the universe was more important than worldly dynastic rule" (el Mansour, pp. 58, 61-62).

Revealing the sultans' lack of absolute power is the following fact: the gradual erosion of the hurm privileges during the $19^{\text {th }}$ century was made possible only because (reformist) ulema themselves decided to attack popular religion as practiced by the zawiya and the religious brotherhoods, and thereby played a significant role in delegitimizing the hurm

\footnotetext{
${ }^{19}$ The idea of sanctuary is as old as religious belief itself, and it was certainly an integral feature of Semitic religious tradition (el Mansour, p. 50).
} 
institution. Sultans then succeeded in obtaining fatwas from the ulema authorizing them to invade the territory of a hurm with a view to arresting a mutinous governor, on the grounds that he was using it as a means to transgress the divine law (el Mansour, pp. 65-67).

\subsection{Politics and religion under a state crisis caused by lawlessness}

The relationship described above between politics and religion could be deeply disturbed when the state fell into a state of prolonged crisis. This typically happened under the two polar circumstances of lawlessness and unrestrained despotism: (i) a political vacuum created by weak central power, or (ii) a despotic rule resulting in acute people's oppression and deeply entrenched corruption of the leadership. Under such circumstances, there is a tendency for religious authorities and groups to play a more active role in politics and to reassert themselves as the most effective shield against the vicissitudes of power. Let us consider the two situations in turn.

In periods of a power vacuum, contending political factions vie for political power causing a state of anarchy and lawlessness under which people endure many hardships. Religious figureheads are then tempted to come out of their seclusion in order to substitute for missing central power or to help people in distress. To return to our Moroccan example, it is a well-substantiated fact that in periods of political vacuum, sanctuaries became more numerous and were more frequently solicited. This is not surprising since in an environment characterized by instability and violence, they became more useful both as islands of peace and as sites through which conflicting tribes and other social groups were able to work out non-violent solutions (el Mansour p. 57, pp. 69-70).

In Ottoman Turkey, a state in which the sultan held considerable powers and succeeded in incorporating the entire (religious) legal community into the state bureaucracy 
after the $15^{\text {th }}$ century ${ }^{20}$, his control over the ulema tended to decline during periods of state crisis. Thus, dervish orders were spawned by the chaos of cultural and physical frontiers that accompanied the waves of Turkoman migrations. These fraternities, which existed "in bewildering variety", could represent "exceptional sensibility to political and social injustices" (Goffman, pp. 73-74). They came to form an extensive network of deviant Sufis, occasionally operating as centres of opposition to the Ottoman state and its policies. When the regime was fragile, such as was certainly the case under Mehmed I, they could even gather a wide range of disgruntled Ottoman subjects into a massive rebellion (1416) (Goffman, p. 75).

The case of Iran ("Persia" prior to 1935) is equally interesting, and deserves special attention in the light of the comparatively large influence exerted by the religious authorities in recent times, up to the present. While the Safavids largely succeeded in making religion subservient to their own ends and in building a strong and centralized state that created political stability and economic prosperity, the situation radically changed after their demise as a result of the rebellion of an Afghan chieftain in 1722 (Algar 1969, Keddie 1969, 1971, and 1999, Abrahamian 1982, Arjomand 1984, Floor 2000, Cleveland 2004, pp. 51-55 and 109-116, Martin 2005, Gleave 2005). There followed a long period of chaos dominated by tribal warfare and weak, short-lived states until the Qâjar dynasty was eventually consolidated (1794) to remain (nominally) in power until the 1920s. The Qâjars, however, "never succeeded in recreating the royal absolutism or the bureaucratic centralism of the Safavids" (Cleveland, p. 55). In actuality, powerful centrifugal forces had taken root in Iran during almost the whole $18^{\text {th }}$ century, and the Qâjar shahs were never able to mobilize sufficient resources to bring them under control. Administrative instability, insecurity and low legitimacy were the hallmarks of most of their rule. ${ }^{20}$ In the words of Cleveland, "the entire religious establishment held office at the pleasure of the
sultan" (p. 48; see also Inalcik 1973, Inalcik and Quataert 1994, Goffman 2002, Imber 2002). 
Of more direct relevance to us is the rise to prominence of the Shi' a religious establishment during those chaotic times. The ulema began to function independently of the government and, backed by a population that granted them extensive authority in religious and legal matters, they constituted a powerful force of support of, or opposition to, the policies of the shahs. According to William Cleveland, popular belief held that the rulings of mujtahids (learned individuals qualified to exercise ijtihad, that is, to interpret the shar' ia) were more authoritative statements of the will of the Hidden Imam than the proclamations of the shahs who made no claims to divinity. Thus, "if a mujtahid denounced a royal decree as incompatible with the teachings of Islam, then believers were enjoined to accept the mujtahid's decision. In this way, the ulema gained a powerful voice in Iranian political life" (p. 111). ${ }^{21}$ The growing importance of religious courts (the shar') was reflected not only in their rising number, but also in their rather wide area of competence (they could deal with commercial and many other matters), and in the preference given by many people to religious over official courts (when the choice was possible) whose judges were considered particularly corrupt and unreliable (Floor 1980, Gleave 2005).

Worthy of special attention is the strong alliance that gradually developed between the merchants and the ulema. Resistance against inept and corrupt political rulers in Tehran and against unfair accommodation of European economic interests actually united these two classes of the population. The first great popular demonstration, known as the Tobacco Protest, was directed against a particularly unjust concession granted to foreign interests (Keddie 1966, Rodinson 1966, p. 166, Cleveland 2004, Gleave 2005). ${ }^{22}$ Significantly, the

\footnotetext{
${ }^{21}$ An intense debate took place between the Akhbari and the Usuli schools regarding the role of the ulema. Whereas for adherents of the former, Muslim believers are quite able themselves to interpret the Qur'an and the sayings of the Prophet, adherents of the latter think that only the ulema are qualified for that purpose. In the course of the $18^{\text {th }}$ century, the Usuli school won a decisive victory over the Akhbari school.

${ }^{22}$ In 1890, the corrupt and inefficient government of Nasir al-Din who wanted to open Iran to foreign economic exploitation awarded a British capitalist (G.F. Talbot) the exclusive right to produce, sell
} 
mass protests were organized and led by members of the Shi'a ulema who "urged the population to join them in preserving the dignity of Islam in the face of growing foreign influences; they portrayed the shah's concession as a transgression of the laws of Islam and used their independent power base to denounce the government” (Cleveland, p. 115). In 1891, a mujtahid from Shiraz issued a decree (fatwa) declaring tobacco consumption as an impious act (an offence to the Hidden Imam) that will be considered as unlawful till the cancellation of the concession. The Iranian people responded by boycotting all tobacco products, and after huge demonstrations in Tehran and other important cities, the government was forced to backtrack in 1892. Considerably weakened by this event, it completely reversed its policy and became openly hostile to contact with the West. The essential lesson to draw from this example is that a religious authority could use its power of interpretation (ijtihad) to confront a government's economic policy. To the class of the ulema, it had become clear that "the Iranian people were receptive to calls for political activity based on Islamic frames of reference" (Cleveland, p. 115).

Frequent abuses committed by government agents thus largely explains why Iranian merchants continuously sought the protection of a conservative religious class and refrained from demanding serious reforms. Only at the beginning of the $20^{\text {th }}$ century did some of them actually dare to provide funding to reform movements (Keddie 1999). On the other hand, a crucial factor behind the independence of the religious establishment from the central government lay in its financial autonomy. This is partly the consequence of the fact that in Shi'a Islam the ulema rather than the temporal authority are entitled to receive the charitable donations Muslims must pay (the zakat). In addition, the ulema received income from teaching, administering waqfs (Muslim charitable institutions) ${ }^{23}$, registering deeds and titles,

and export the country's entire tobacco crop. Since tobacco was such a vital commodity in the economy, this decision immediately aroused tumultuous mass protests.

${ }^{23}$ More precisely, a waqf consists of a private immovable property turned into an endowment intended to support any social service permissible under the Islamic law (Kuran 2004b, p. 75). 
and maintaining mutually advantageous ties with urban merchants. Since these incomes were largely used to provide educational services and social assistance to the needy, the influence and popularity of the ulema were growing: their image as the true protectors of the people was all the more attractive as the government was increasingly viewed as corrupt and impious (Cleveland, p. 113). ${ }^{24}$

\subsection{Politics and religion under a state crisis caused by unrestrained despotism}

Pre-colonial Morocco and Safavid Persia were characterized by a politico-religious equilibrium in which a powerful ruler had the upper hand and a religious institution played the role of a buffer against his potential abuses and of a mediation mechanism through which political conflicts could be resolved. By tolerating such an institution and respecting its autonomy, the ruler thus committed himself to moderating his actions and negotiating with political opponents rather than crushing them. Note that this equilibrium is different from the political equilibrium of representative democracy in which the buffer, instead of consisting of a shelter, a refuge or an asylum, takes on the form of a body, the parliament, endowed with genuine decision-making powers in critical matters.

In the end, it is the legitimacy of the Islamic faith in the people's eyes that confers credibility upon a strong ruler's promise of moderation: in the absence of it, he could always choose to invade the sacred sites (a sanctuary or a mosque) whenever it suited his purpose. The importance of religious beliefs is, therefore, the answer to Acemoglu and Robinson's question as to why institutions, in this case, religious institutions, provide commitment (2006, p. 177-79). The politico-religious equilibrium thus obtained is nonetheless more inherently unstable than what might appear at first sight. Using his double quality as both a political

\footnotetext{
${ }^{24}$ Thanks to their financial independence, stresses Ayatollah Motahhari, the ulema are able not only to respond to the demands of the people, but also "to stand up to governments and fight against their excesses and their cruelty" (Rahnema and Nomani 1990, p. 46).
} 
leader and the guardian of the faith, the ruler may be tempted to confer upon himself the legitimacy accorded by Islam with a view to getting rid of countervailing powers, institutional buffers, and political dissent. True, to acquire sufficient religious credentials, he needs to secure the cooperation of at least some prominent ulema (as in the aforementioned case, where Moroccan sultans strove to undermine the privileges of the sanctuaries), but this may not be too difficult given the absence of a strictly uniform interpretation of the Islamic law. Obviously, as demonstrated by Egypt (under Mubarak) and the Saudi royal family, the more divided the religious class, the easier for the political ruler to have his own way without incurring the risk of having to contend with significant religious forces.

An obvious instance of such a concentration of religious and political powers occurs when an ambitious ruler uses the banner of Islam to extend his control over a rebellious territory, or to unify a fragmented political space. For example, when Timur (1336-1405), known as Timur Lane or Tamburlaine, began to reconquer the old Mongol territory, he not only claimed Mongol descent, but also developed a bigoted version of Islam that bore little relation to the conservative party of the ulema: "he saw himself as the scourge of Allah, sent to punish the Muslim emirs for their unjust practices" (Armstrong 2001, p. 91). On the other hand, the first (internationally recognized) king of Afghanistan, Abdur Rahman (1880), worried about the threats to his central power coming from the main tribes of the country and constantly referred to Islam as a way to establish his authority. In order to pacify the northern opposition and to extend his authority to the east and the centre, he even decided that he was the only person allowed to declare the jîhad (Nahavandi 1999, p. 89). Motivated by the desire to establish central law and order in the country, rulers from Kabul have always tried to use the shari'a as a substitute for a variety of tribal laws.

Rahman was thus following the route pointed to a long time ago by Ibn Hanbal, the first Islamist thinker and the founder of one of the four juridical schools of Sunnite Islam (first 
quarter of the $9^{\text {th }}$ century), who reflected upon the best ways to avoid the violent upheavals and murderous tribal rivalries that Islam had witnessed during its first centuries (see above). Unlike those who argued for a retreat from the ugly realities of world politics through some form of mysticism or theological quietism (particularly prominent among the oppressed Shi'ites who took refuge in Messianistic expectations, the New Messiah or Hidden Imam being supposed to reincarnate Ali) ${ }^{25}$, Hanbal stressed the need to follow the letter rather than the spirit of the Qur'an. To reconcile the contending factions and reach a large consensus among the Muslims, he proposed to ban all personal opinions and to rally the whole community of believers around a unique truth. Reading of the Qur'an had to be literal, avoiding any allegorical exegesis. Indeed, strict adherence to the Islamic law had to replace particularized adherence to tribal laws so that segmented ties based on kinship could give rise to harmonious relationships grounded in a religion of universal brotherhood.

Several centuries later, Ibn Taymiyya (1263-1328) from Damascus and one of the foremost religious writers of the Mamluk period followed in Hanbal's footsteps. Like him, he was preoccupied by the divisions within the Islamic world and believed that the unity of the umma (a unity of belief in God and acceptance of the Prophet's message) is what matters most, even if this principle does not imply political unity. His views were even more radical than those of Hanbal, in part because he believed that an important duty of the sovereign is to disseminate the Muslim faith beyond the confines of the existing Muslim community and to have recourse to the jîhad, the holy war, toward that purpose. In short, every Muslim believer must be a fighter for his faith, and the holy war is as important as prayer in his conception (Hourani 1991, pp. 179-81, Meddeb 2002, Chap. 9). ${ }^{26}$

\footnotetext{
${ }^{25}$ This is a reaction similar to that of the Pharisees under the Roman Empire.

${ }^{26}$ For Taymiyya, two pitfalls must be avoided: that of a prince who does not use his wealth, army and power to strengthen religion (the way of Christianity), and that of a powerless religion that is deprived of financial and monetary resources.
} 
Even when a country is politically integrated, instrumentalization of Islam may be an attractive option for contested rulers willing to suppress dissent and establish an autocratic system rid of all genuine countervailing powers or buffers. To some extent, such a possibility reminds us of the political situation that prevailed in the period preceding the formation of the Islamic law and the establishment of the legal community when rulers were very autocratic, such as was observed during most of the rule of the Umayyads and the early Abbasids (Cosgel et al. 2007, p. 18).

What needs to be emphasized is that in these circumstances the growing role of religion is the outcome of a deliberate strategy of the political ruler. Recent history actually offers us many striking examples to the effect that cynical political rulers, often with a secular background, use Islam as a readily available ideology and instrument of legitimacy to deflect criticisms and entrench their power and privileges. They are thus able to escape the consequences of their misrule and to avoid the hard task of trying to understand the causes of their country's predicament and undertake the necessary reforms, or else quit power. When political opposition takes on the form of Islamist movements that question the legitimacy of the ruler on religious grounds, such as is observed when secular-rationalist ideologies remain weak, the above strategy that allows rulers to use Islam as a counter-attack device appears to be the most cost-effective.

In Pakistan, Zulfikar Ali Bhutto (executed in 1977) had been a modern secular politician with social democratic ideas, yet as a prime minister and out of political expediency "he increasingly appealed to Islam and advocated the Islamization of the country" (Nomani and Rahnema 1994, p. 121). ${ }^{27}$ The move was pursued by General Zia ul-Haq; to consolidate

27 The idea of creating a separate Indian Muslim state was first put forward by Sir Mohammed Iqbal (1876-1938) in 1930. If we follow the account given by Naipaul (1982, pp. 88-90), characterization of the difference between Christianity and Islam in the thought of Iqbal is very close to the account given by Bernard Lewis. Unlike what is observed in Christianity, religion for a Muslim is not a matter of private conscience or practice. There never was a specifically Christian polity, and in Europe after Luther, the "universal ethics of Jesus" was "displaced by national systems of ethics and polity". In 
his power and restore the legitimacy of the military after the humiliating defeat of the army in the 1971 war against India and the secession of Bangladesh, he chose to present the military as "the ideological vanguard of an Islamic state", and did not hesitate to declare "that he was not responsible to anyone except Allah" (Nomani and Rahnema 1994, pp. 126-29). After proclaiming himself president of Pakistan (September 1978), he vowed to bring the economy, judiciary, and education further in line with the shari' $a$ and announced the enforcement of Islamic penal laws, introduced the Islamic tax, and created Islamic banks. With the aid of Saudi financiers and functionaries, he established numerous madrasas throughout the country and thus helped to create a base from which the Taliban government could later develop. Interestingly, the ulema played a very minor role in the Islamization of Pakistan (Zakaria 2003, pp. 145-46, Piquard 1999).

In Sudan, which was established as a secular state by the 1973 constitution, Gaafar Numeiri initiated a rapprochement with Islamic factions as soon as his deeply corrupt patrimonial policies aroused bitter political opposition in both the north and the south of the country. Two prominent Islamic politicians, including Hassan al-Turabi (leader of the Muslim Brotherhood and founder of the National Islamic Front whom he had previously imprisoned), entered his government in 1977. Appointed attorney-general, Turabi exerted steady pressure for the Islamic reform of the legal system, and in 1983, Numeiri completely reversed his previous policy by declaring an 'Islamic revolution' and transforming the Sudanese state in an Islamic republic to be governed by Islamic law. He even attempted, albeit unsuccessfully, to proclaim himself as Imam accountable only to Allah. Moreover, he demanded an oath of unconditional allegiance from all members of the civil service and

Islam, there cannot be a Luther because there is no Islamic church order for a Muslim to revolt against. Muslims, to be true to Islam, need a Muslim polity, a Muslim state in which to enforce their religious ideal. This ideal, indeed, is organically related to the social order that corresponds to it so that the rejection of the latter will eventually lead to the rejection of the former (pp. 88-89). What needs to be emphasized, however, is that the political founder of Pakistan, Ali Jinnah, was driven by secular ambitions and only wanted a state where Muslims would not be swamped by non-Muslims (p. 90). 
judiciary, thereby causing the departure of prominent secularists and the dominance of the civil service, the army and the financial sector by Islamists.

He also let Turabi draft the Criminal Bill (presented to parliament in 1988) which included an ominous provision for outlawing apostasy sufficiently vague to allow its application to be politically determined (de Waal 1997, pp. 88, 91, Meredith 2005, pp. 35657). Numeiri's execution of Mahmud Muhammad Taha, the founder of the Republican Brothers, on the charge of apostasy (1984) offers a perfect illustration of the cynical use that can be made of the Bill. The fact is that "opposition to an Islamic government can be, and has been, defined as an act of apostasy", not only against secular Muslims and other political opponents (e.g., communists) but also in the harassment of other Islamic sects (such as the Khatmiyya, Ansar and Ansar-Sunna) that were regarded as a threat to the ruling power (Johnson 2003, p. 129). ${ }^{28}$ Omer el Bashir, did not depart from the line adopted by his predecessor. In particular, he promulgated the Sudanese Penal Code of 1991, which included the aforementioned provision on the crime of apostasy, ${ }^{29}$ and he made training in Islam compulsory for civil servants, teachers, students and higher-education candidates. (de Waal 1997, p. 98, Johnson 2003, p. 128, Meredith 2005, p. 589).

The case of Algeria deserves special attention because there the radical Islamist movement known as the FIS (the Islamic Salvation Front) has actually been encouraged by President Boumediene when his hold on political power was seriously challenged in 1968 by a rising opposition made up of intellectuals, students and trade unions. As early as 1965, on the occasion of the state coup that brought him to power, a bizarre alliance was sealed between the new socialist, anti-imperialist regime and the ulema, granting to the latter the

\footnotetext{
${ }^{28}$ That the indictment of apostasy can be turned against Islamic people is also attested by the attitude recently displayed by ultra-puritan Sunnis, known as takfiris, whose belief in Shi'a perfidy prompted them to denounce the Shi' as as apostates from Islam and to claim that it is therefore legal to kill them (Economist 2006a, p. 22).

${ }^{29}$ In addition, a presidential decree in 1991 limited women's activities and imposed upon them strict dressing codes to be enforced by the Guardians of Morality and Advocates of the Good (Meredith 2005, p. 589).
} 
right to lead the arabization of the country and to manage the education system (including the right to rewrite the school textbooks). It is thus in complete agreement with the regime that the religious dignitaries started to spread the message of a conservative Islam through the creation of a wide network of Islamist institutes directly governed by the Ministry of Religious Affairs. Radical views inspired by Taymiyya, Qutb and Mâwdudi (more will be said about them later) were diffused legally, and an idea which gained increasing currency is that colonization of Algeria had been possible only because of the degeneration of the precolonial state. The solution had to rest on a return to the sources of Islamic culture (Bouamama 2000, Chap. 3).

When secular, democratic opposition intensified, the regime gave more leeway to the ulemas and to the more reactionary forces among them. They started to assert their authority more aggressively and to meddle openly in matters of social policy (such as dressing codes, amount of brideprices, etc.). The idea of a "renaissance" of the country based on the Islamic tradition was explicitly taken over by the government ${ }^{30}$, and the Islamic character of the Algerian state, embedded most explicitly into the National Charter, was considered as the ideological and political programme of revolutionary Algeria: $:^{31}$

The Algerian people are an Arab and Muslim people. Islam is the religion of the state, and one of the fundamental components of the national Algerian personality... It is to Islam, the religion of militant endeavour, of rigour, justice and equality, that the Algerian people returned to in the darkest times of the Crusades and colonial domination, and it is from Islam that they drew the moral force and spiritual energy required to sustain hope and achieve eventual victory. Islam has shaped the Algerian society and made it a coherent force, attached to the same land, the same beliefs and the same Arab language that enabled Algeria to start again contributing to the works of civilization. (quoted from Bouamama, $p$. 161 , my translation).

\footnotetext{
${ }^{30}$ Thus, the Minister of Information and Culture, Ahmed Taleb Ibrahimi, declared that "a cultural revolution implies a return to the sources" and that Islam represented the central value upon which to build the new Algerian society: "the other values owe their importance, their existence and their prestige only to their articulation with Islam or to the fact that they are inspired by or subordinated to Islam" (cited from Bouamama, p. 163).

${ }^{31}$ It is revealing that this passage of the 1976 version of the charter was not amended in 1986 when the so-called liberal regime of President Chadli decided to revise it, mainly to suppress all references to socialism (Bouamama, pp. 161-62).
} 
In Algeria, therefore, Islam was "nationalized" and cynically used by the state to legitimize repressive policies and mobilization (Layachi 1995, p. 180, Owen, 1992 p. 41). This is the usual story of authoritarian rulers who do not hesitate to (discreetly) support or coopt extremist movements, whose ideological platform is often based on religion or ethnicity, to fight political opponents threatening them. Power elites used Islam and the language of religion in self-defence against opposition groups that were frustrated at the failures of corrupt, secretive, authoritarian, and ineffective states that did not deliver on what they promised (Hourani, pp. 452-53). ${ }^{32}$ They were particularly vulnerable to attacks coming from Islamist movements since, in the lands of Islam, anyone can oppose the state on the grounds that it is insufficiently Islamic (see above): Islamist clerics may decide that a ruler is not a 'good Muslim' and does not deserve to rule. This largely explains why secular regimes, including that of Egypt, began to rest their legitimacy in religion (Hourani, p. 452). ${ }^{33}$ The same principle applies to the secular regimes of Syria and Iraq (Hourani, pp. 452-53). In Iraq, Baathist ideology was based on pan-Arabism "whose spirit is Islam" (Makiya 1989, p. 198).

\footnotetext{
${ }^{32}$ The support given by powerful segments of society to governments has very often been passive in Arab countries, partly because they did not participate actively in the making of decisions. "In most regimes this was done at a high level by a small group, and the results were not communicated widely; there was a tendency for rulers, as they settled into power, to become more secretive and withdrawn - guarded by their security services and surrounded by intimates and officials who controlled access to them- and to emerge only rarely to give a formal explanation and justification of their actions to a docile audience. Beneath this reason for the distance between government and society, however, there lay another one: the weakness of the conviction which bound them to each other" (Hourani, p. 454).

33 Malaysia attests to the continuing risk of political instrumentalization of Islam, even in comparatively developed Asian countries. There, indeed, resentment among Malays against the economically successful Chinese community took the form of an appeal to Islam (unlike the Chinese, Malays are Muslims) and a claim for establishing an Islamic state in the country. If this outcome was eventually avoided, it is because a political compromise could be found whereby, at the urging of the dominant (non-Islamist) party in power, the Chinese agreed to support a policy of positive discrimination in favour of the Malays (Horowitz 1985, Matthew 1990). This delicate balance seems to have been recently disturbed, as attested by the inflammatory speeches at the annual congress of the ruling United Malays National Organisation (UMNO) in mid-November 2006. In these speeches, indeed, the necessity to defend the race and religion of the Malay Muslim majority against the ethnic Chinese and Indian minorities has been overly stressed, and no less than the education minister brandished a keris (traditional dagger), only to be asked by another delegate to start using it (Economist 2006b, pp. 57-58).
} 
It stressed the exceptionalism of the Arabs whose national awakening was bound up with a religious message and obligation (Makiya, p. 211, Dawisha 1999).

As is evident from the above accounts, radical interpretations of Islam may be encouraged by political rulers eager to suppress dissent and achieve absolute power. Radicalization then occurs as a movement born of the spontaneous articulation of popular discontent to which the political elite then respond by themselves using Islam as a counterattack tactic or as a movement stimulated from above in order to quash opposition. When both opposition groups and the state thus invoke Islam as the main justification for their actions, an obscurantist deadlock is created in which all political opinions and judgements have to be expressed in the language of religion. Rather than a merging of religion and politics, the problem appears to be the easy manipulation of religion by the state.

To understand the emergence of Islamist movements in present-day Islamic world, it is not enough to cite the inept and corrupt character of most prevailing political regimes, as well as the cynical manipulation of religion by some despotic rulers. A conjunction of historical circumstances, political or military events, and power games at the international level have obviously complicated the task of Middle Eastern countries confronted with the challenge of modernization and economic progress in the face of powerful external competition. This international context is highlighted in Section 4 below.

Afterwards, the natural question to be asked is why changes in institutions, norms and behavioural patterns did not take place in the lands of Islam to allow them to compete effectively with the fast-growing countries of the leading core of the world. Part of the answer has been provided in the above analysis: in the Middle East, the cost and risk of reforming institutions are particularly high because of the easiness with which Islam can be opportunistically invoked to block movement toward progress, not because of any intrinsically retrograde aspect of the faith, but rather because of the absence of a religious 
hierarchy able to impose an Islamic orthodoxy. In the words of Zakaria, "The Muslim caliph was first and foremost a prince; he was not a pope, and he did not have to contend with one... rulers could always find some priest to legitimate them, and rebels could find inspiration in the words of others" (p. 147). In the Christian world, instrumentalization of religion by political rulers also occurred, yet the presence of a strong Church structure responsible for enforcing a uniform interpretation of the faith had the effect of limiting the powers of both the rulers and their contenders to manipulate doctrinal tenets at will.

There is another reason why the cost of institutional reforms (including reforms of the political system) has been comparatively high in the lands of Islam in modern times. As argued by Timur Kuran, reforms in a number of key areas are especially hard to achieve because they would run counter to the legacy of the classical Islamic system, hence the existence of an "institutional trap" impeding modernization of Middle Eastern countries. The diffusion of modern ideologies grounded in secularist and rationalistic worldviews is thereby made more difficult. Kuran's approach is presented and discussed in Section 5.

\section{The rise of Islamist movements}

\subsection{Revived Islamist doctrines and unique diffusion opportunities}

Guiding present-day Islamist movements is the thinking of a few religious reformers who drew inspiration from the writings of both Hanbal and Taymiyya. The first of them is Muhammad ibn Abd al-Wahhab (1703-1792) who preached the return to the teaching of Islam as understood by the followers of Hanbal in the context of central Arabia in the early eighteenth century. This meant strict obedience to the Qur'an and Hadith as they were interpreted by responsible scholars in each generation, and rejection of all that could be regarded as illegitimate innovations, including reverence to dead saints as intercessors with God and the special devotion of the Sufi orders (Hourani, pp. 257-58). To preserve his creed, 
the Wahhabite does not hesitate to destroy the relics of the past so that any confrontation between myth and historical document can be avoided.

The movement created by al-Wahhab was not important in his own time (he was actually a poor philosopher, not well regarded by Arab colleagues), but was to have wider significance later. This is because he was linked to the Seoud tribe, which was striving to take hold of power by conquering the Arabian deserts. The eventual conquest of Arabia by the Seouds and their support given to the puritanical doctrine of al-Wahhab proved to be a decisive factor in modern Muslim history. ${ }^{34}$ Much in the line of what has been said before about political instrumentalization of Islam, the Saudi royal family is essentially a secular polity that has co-opted a religious elite and used Islam in order to consolidate a Saudi national identity and thereby reinforce its own legitimacy (Al-Rasheed 1996, 2002, and 2006, Nevo 1998). Abdelwahab Meddeb portrays them crudely as a bunch of hard-nose businessmen (more exactly, rentiers) eager to provide an Islamic façade behind which to hide their unrestrained capitalist practices $(2002$, p. 125). In the context of the present discussion, the key point is that the wealth of Saudi Arabia, thanks to the abundance of oil in its soil, allowed it to play a major role in the lands of Islam. Many Muslims migrated to Saudi Arabia to work as migrants and later returned to their country of origin, while the government of Saudi Arabia used its immense financial resources to disseminate Wahhabism throughout the Muslim world and beyond.

About two centuries after al-Wahhab, the puritanical interpretation of Islam was revived by Abû al-A'lâ Mawdûdi (1903-1979) in Pakistan and by his fervent disciple Sayyid Qutb (1929-1966) in Egypt. These two thinkers had a deep influence on today's Islamist movement, in particular, on Ussama ben-Laden (Saudi Arabian) and his lieutenant in el

\footnotetext{
${ }^{34}$ From the very beginning of Saudi Arabia, the king was regarded as the guardian of Islam and the holy cities of Mecca and Medina and was supposed to maintain Islamic values in the community and throughout the world (Nomani and Rahnema, pp. 137-140).
} 
qâ'ida, Ayman al-Zawahri (Egyptian). While Mawdûdi did not call for war, even though his writings lead to the conclusion that war is required, Qutb claimoured for the reactivation of the jîhad and the use of sheer violence to achieve the aims of the movement. For Mawdûdi, there is legitimacy in God only and the whole political realm must be reduced to the divine realm: the religious principle must be put back at the heart of social life with no room for anything else. For Qutb, the Islamic society is one that accepted the sovereign authority of God and regarded the Qur'an as the source of all guidance for human life. The struggle should aim at creating a universal Muslim society, thus marking the end of the Western world that cannot provide the values needed to support the new material civilization. Against the moral decay of the Western civilization, Muslims must thus oppose an ethics reconstructed on the basis of Islam's own origins. It is only after having completely submitted to God, as God required, that man will be emancipated from all the servitudes of the present century.

In Egypt, Qutb joined the Muslim Brothers, an Islamist movement created by Hassan al-Banna (1906-1949), who was himself deeply influenced by his master, Rashid Ridha. Followers were to live according to the shari'a, purify their heart, and form the nucleus of dedicated fighters of the Islamic cause, which implies their readiness for violence and martyrdom (Hourani 1991, pp. 445-46, Meddeb 2002, pp. 114-15 and 121-22). Qutb had a decisive influence on this movement and led it into open opposition to Nasser. He was himself arrested, tried and executed in 1966. The initial programme of the Islamists was thus to overthrow the corrupt regimes prevailing in Arab lands. It is under peculiar circumstances, the refusal of the US government to honour its promise to remove its military bases from Saudi Arabia after the end of the Kuwait war, that ben-Laden decided to re-frame the priorities of el qâ'ida by targeting the United States and the Western world as the principal enemy. Since he brought with him most of the financial resources of the movement, other leaders such as al-Zawahri, had to give in, albeit reluctantly. 
It is thus in continuous go-and-return movements from one bank of the Red Sea to the other that the first operational link between radical fundamentalism and Wahhabism was woven during the 1970s, yet a second, far more critical conjunction of events was to happen in the early 1980s in Afghanistan and Pakistan, in the very country where Mawdûdi propagated his ideology among his own brethern and in their own language (Meddeb 2002, p. 122). It bears noting that, even among the Mujahiddin who fought against the Soviet troops, there existed various contending factions with different sorts of Islamic creed. They united together to oust the Soviet troops, yet tensions among them have always been serious and immediately resurfaced as soon as victory was obtained. With the Russians out, Gulbuddin Hekhmatyar, the leader of the most extremist faction among the Mujahiddin, became the prime minister of the Afghan government. ${ }^{35}$ Since internal confrontations between the contending factions of the victors did not stop, the government soon collapsed, and a new radical movement, that of the Taliban, came to power, quickly joined by the extremist Islamist factions of the Mujahiddin. Like Ibn Hanbal twelve centuries earlier and like king Rahman toward the end of the $19^{\text {th }}$ century (see above), the Taliban were convinced that a uniform, rigid interpretation of the Qur'an is the only way of bringing unity and restoring order among the feuding local tribes and warlords.

We have still trodden only half of the way toward answering our first question since it remains to be explained why the puritanical interpretation of Islam has fallen on such compliant ears. This query is particularly pertinent in the case of Egypt, traditionally one of the major sources of deep Muslim philosophical thinking and where the movement of the Muslim Brothers played a major role in spreading such a radical version of the faith.

\subsection{A modernization crisis compounded by military defeats}

\footnotetext{
${ }^{35}$ Ironically enough, he was strongly supported and financed by the US (through the CIA), Pakistan (through the ISI, the Intelligence Service that rules Pakistan behind the screen), and Saudi Arabia
} 
What is it that recently caused the Islamic world to turn more radical? The answer seems to be that radicalization of Islamic ideology is a consequence of a deep economic, social and military crisis faced by Muslim societies. This crisis has its roots in the decline of the Arab civilization and its failure to meet the challenge of modernization posed by the Western world. Thus, according to Mohamed Chérif Ferjani, the Arabs are torn between two models of civilization, the European civilization that challenges them and the Arab-Muslim civilization that provides them with a response to that challenge. The choice between the two models is made especially difficult because of a "psychic tension" amplified by the acute awareness of the reality of decadence of the Arab world. A fundamental trait of most contemporary political Arab writings, whether left- or right-oriented, is thus their "obsession with past grandeur" that prevents any strand of thought from envisaging progress, modernization and development in terms of a rupture with the past, such as happened with the Enlightenment Revolution in Europe. Instead of 'progress', Arab authors prefer to think of a 'renaissance' ("reviving the past grandeur"); that is, they prefer to think "in magical and mythical terms": "It is as though the present and the future cannot have legitimacy if they are not rooted in the historical and cultural patrimony" (Ferjani 1991, pp. 133-34, my translation; see also Meddeb 2004). Note that this analysis also applies to the deceptively secular ideology of Baathism in which “Arabism's most basic model always resided in its own past”, and the consciousness of pan-Arabism has been ideologized in such a way as to borrow virtually nothing of the constellation of values associated with the European Enlightenment aside from an admiration for socialist economies (Makiya 1989, pp. 189-212).

Other regions of the world have actually gone through such a modernization crisis (see, e.g., Janos 1982), and eventually succeeded in resolving it (think of the changes undergone by Japan while shifting from the Tokugawa to the Meiji era). What makes the present predicament of the Muslim world, and the Arab world in particular, so persisting and 
vicious is the fact that it is sustained by humiliating military setbacks (which actually prolong a long tradition since the Arabs have gone from defeat to defeat since the victory of the Mongols over the Abbasids in 1258) and the openly declared support of the Western superpower in favour of a small-sized enemy embedded in the body of the Arab world. In the words of Hourani,

The events of 1967 [a crushing military defeat of the Egyptian Army at the hands of the Israelis], and the processes of change which followed them, made more intense that disturbance of spirits, that sense of a world gone wrong, which had already been expressed in the poetry of the 1950s and 1960s. The defeat of 1967 was widely regarded as being not only a military setback but a kind of moral judgement. If the Arabs had been defeated so quickly, completely and publicly, might it not be a sign that there was something rotten in their societies and in the moral system which they expressed?... the problem of identity was expressed in terms of the relationship between the heritage of the past and the needs of the present. Should the Arab peoples tread a path marked out for them from outside, or could they find in their own inherited beliefs and culture those values which could give them a direction in the modern world? (pp. 442-43; see also Kassir 2004)

To the extent that the first option appears as a surrender of independence to the external world, preference tends to be given to the second option. In the words of Galal Amin, "To be healthy, their political and economic life should be derived from their own moral values, which themselves could have no basis except in religion” (quoted from Hourani, p. 443). In the same vein, Peter Mansfield wrote that after 1967 there was a sudden reversal of the common opinion that the Arabs were determined to catch up with the West's material and technical progress; as a matter of fact, "secular Arab nationalism had been proved a failure and was dead; the masses would reject Western progress and turn to fundamentalist Islam as their only hope” (2003, p. 325; see also Dawisha,2003). This fundamentalist Islam provides a kind of escape valve allowing political rulers to eschew reforms of their country's economic and political system, an observation that dovetails with the above-reported finding of El Badawi and Makdisi that in Arab countries interstate conflicts and wars tend to promote authoritarianism rather than a shift toward democracy.

All this is strangely reminiscent of the rebellion led against the Ottoman government in the early $17^{\text {th }}$ century by young and idle students from religious schools. Their leader was a 
gifted preacher, Kadizade Mehmed, whose sermons emphasized the evils of innovation: "every innovation is heresy, every heresy is error, and every error leads to hell" (quoted from Goffman 2002, p. 117). In the words of Daniel Goffman, his followers considered the Ottoman military and high Ottoman society as "inept and morally bankrupt", and they "envisioned the recurring debacles on the battlefield as well as the persistent palace scandals as manifestations of a turn away from true Islam"... In important ways, they constituted a forerunner to Islamic reformers in later centuries who, whether Ottoman, Egyptian, Wahhabi, or Iranian, consistently have argued that the West has defeated Islamic states only because their ostensibly Muslim leaders have forgotten their religious roots. Bring back the Muhammedan state, they all argue, and Islam will again take up its leading rank in the world order” (p. 119).

To whom does the new literal and puritanical Islam appeal most? Not to the poorest of the poor, for whom Westernization is magical since it means an abundance of food and medicine, nor to the rural dwellers who are immersed in "a kind of village Islam that had adapted itself to local cultures and to normal human desires", an Islam that is pluralistic and tolerant, allowing the worshipping of saints, the singing of religious hymns, or the cherishing of art, all activities formally disallowed in Islam (Zakaria 2003, p. 143). ${ }^{36}$ Religious and cultural syncretism was thus an hallmark of most rural societies in the lands of Islam (see above, Section 2). ${ }^{37}$ The people to whom Islam appeals most are "the educated hordes entering the cities of the Middle East or seeking education and jobs in the West" (Zakaria, p. 144). Also, being cut off from the ties of kinship and neighbourliness to which they were accustomed in their village, rural migrants found a sort of compensation in strong Muslim

\footnotetext{
${ }^{36}$ Revealingly, a recent study has shown that in Morocco rural women are more open than more educated urban women to the new Family Code, which contains provisions calling into question the traditional interpretation of the Islamic law regarding men-women relations (Aquil 2006).

${ }^{37}$ In Afghanistan, for example, the village mollah has no relation to the superior clergy: he is the employee of the village community in which he exercises the functions of a rite performer (Nahavandi, p. 86).
} 
urban organizations. In other words, the sense of alienation or loss of identity which they experienced in the cities "could be counterbalanced by that of belonging to a universal community of Islam,... and this provided a language in terms of which they could express their grievances and aspirations" (Hourani, p. 452; see also Roy 2004, pp. 269-70). ${ }^{38}$

Identification with Islamist groups among alienated urban people has been further aided by the fact that in many countries Islamist movements were able to capitalize on the lack of legitimacy of poorly performing states and their failure to integrate the entire population and to increase political participation (many regimes have had only narrow support within particular ethnic, religious or tribal minority groups). They have also filled the gap left by the retreat of the state from the distribution of essential services, such as health, education, and childcare. In Egypt, for example, the number of Muslim NGOs increased from 600 in the early 1970 s to 2,000 in the mid-1980s, and the number of private mosques grew from 14,000 to 40,000 from the early 1960 s to the early 1980 s (Huuhtanen 2005, pp. 78-79; see also Harik 2005 for a detailed review of the Hezbollah's social activities in Lebanon). Typically, a privately-funded Islamic charitable institution provides a range of services that are organized around a private mosque, including donations for the poor, a clinic for health care, a kindergarten and a primary school. Often, these institutions have also founded religious schools, orphanages, and homes for the elderly.

In certain contexts, it must be noted, Islamist doctrines are used by middle class people who want to oppose social groups considered to enjoy undue privileges owing to their tight connection to the regime. In Syria, for example, the Muslim Brothers did not have the same

\footnotetext{
${ }^{38}$ Naipaul's account of Malaysia and Indonesia goes very much in the same direction. For him, indeed, the problem is that people are cut off from their native rural communities whose customs are the outcome of subtle blending of pagan, archaic rites (or Hindu ones) with Islamic tenets, that is, Islam adapted to everyday village realities. Lacking solid landmarks in their new urban, modern life, rural migrants face the threat of a loss of identity. It is in Islam, and in the life of the mosque, with its rules and rituals, that "they found again, or reconstructed, something like the old feudal or rural community that for them no longer existed". After having been exposed to radical Islamic teaching, these new urban dwellers want to purify their native villages, which means cleansing them of pagan (and Hindu) customs (Naipaul, pp. 369, 387).
} 
role as those in Egypt: to a great extent they served as a medium for the opposition of the Sunni urban population to the domination of a regime identified with the Alawi community (Hourani, pp. 457). In the Côte d'Ivoire, the rise of Wahhabism occurred during a period of increasing disruption of the traditional society under conditions of quickly growing urbanization and migration movements after the second world war. The Wahhabite doctrine attracted rich merchants to whom it supplied an ideology that was both anti-establishment and 'bourgeois'. It was anti-establishment in the sense of being opposed to the feudal-like elite of the marabouts, who are at the heart of traditional Islam but are viewed as impostors illegitimately interposing between God and the faithful, and it was 'bourgeois' in the sense of being emancipated from the constraints of the traditional aristocratic system (Miran 2006, p. 250). It is true that its egalitarian discourse also appealed to low caste people willing to liberate themselves from the yoke of the traditional system of hierarchy, but it is only in the 1980s that it started recruiting the urban poor. For them, Wahhabism offered a partial response to their quest for social protection and spiritual advice in a context of urban economic precariousness (Miran, p. 285). ${ }^{39}$ What bears most emphasis is that behind the screen of religious antagonisms lay genuine social and political conflicts:

[T]he battleground was less religious and doctrinal than social and political. As a matter of fact, the recourse to the religious sphere through Wahhabite sectarianism allowed dissatisfied people to express differences that could not be overtly declared in the political realm. Accusations of intolerance, dogmatism and narrowmindedness against the Wahhabites were therefore partly correct: since their separatism was grounded elsewhere, no discussion of a doctrinal nature was possible and no practical compromise could be reached with traditionalist Muslims. (Miran, p. 259 , my translation).

According to the same logic, educated and urbanized women wearing the Islamic veil may do so as a manner of escaping traditional norms that control their physical movements outside the family space. By manifesting their belief in a pure Islam, they claim the right to

\footnotetext{
${ }^{39}$ Until political liberalization began in 1969, Houphouët-Boigny's authoritarian rule succeeded in suppressing the Wahhabite movement rather effectively.
} 
relate directly to God and to dispense with the need to follow repressive rules enforced by men in the name of Islam, thereby obtaining access to public life: the wearing of the veil is "the sign of submission to God and not to men" (Boubekeur 2004, p. 151; see also Adelkhah 1991, Göle 1993). The very fact that the veil allows them to conceal more fully their body provides an astute rebuttal of the argument according to which women's free movements in the outside space threaten the honour of the whole family. As a final example of the importance of the socio-economic context for a proper understanding of the precise meaning of Islamist movements, it is worth remembering the peculiarity of the Iranian case. In this country, responsiveness of certain powerful social classes, including business people, to appeals expressed in religious language is particularly strong because in the country's history, there was a religious leadership able to act as a rallying point for all movements of opposition: relatively independent of the government, and generally respected for its piety and learning, it had always acted "as the spokesman of the collective consciousness" (Hourani, pp. 457-58).

To sum up, in a situation of protracted crisis such as that experienced by the Muslim world, a radicalization of religious beliefs has taken place at the urging of frustrated urban groups and, as we have seen earlier, often by political rulers themselves. Radicalization is more tempting when people can associate the failure of their governments in meeting the challenges of modernity with the failure of secularism and the Western path (most notably in Egypt, Syria, Sudan, and Iraq where socialism, nationalism and secularism were the dominant ideologies of the post-independence ruling elites) and when military defeats are added to disappointing economic performances, corruption and inefficiency of the rulers. In the process, the achievements of Arab secularism in the field of education and legal development (civil and commercial laws were made secular early on, toward the end of $19^{\text {th }}$ century, in countries like Egypt and Syria), for example, are ignored or, worse, they are considered to be a liability. An important outcome of the perceived failure of secularism is that Islam has little 
competition when it comes to articulate popular opposition to authoritarian and corrupt regimes. In the words of Zakaria (pp. 142-143),

The Arab world is a political desert with no real political parties, no free press, and few pathways to dissent. As a result, the mosque became the place to discuss politics. As the only place that cannot be banned in Muslim societies, it is where all the hate and opposition toward the regimes collected and grew. The language of opposition became, in these lands, the language of religion. This combination of religion and politics has proven to be combustible. Religion, at least the religion of the Abrahamic traditions (Judaism, Christianity, and Islam), stresses moral absolutes. But politics is all about compromise. The result has been a ruthless, winner-take-all attitude toward political life. Fundamentalist organizations have done more than talk. From the Muslim Brotherhood to Hamas and Hizbullah, they actively provide social services, medical assistance, counseling, and temporary housing. For those who treasure civil society, it is disturbing to see that in the Middle East these illiberal groups are civil society... If there is one great cause of the rise of Islamic fundamentalism, it is the total failure of political institutions in the Arab world. (see also Kassir 2004, p. 39, Hassan and Kivimäki 2005, p. 133).

Islamist opposition is all the more intransigent as many Islamist teachers are rather poor thinkers prone to extreme simplification: self-proclaimed mollahs form an Islamic 'lumpen-intelligentsia' made of ill-educated, ignorant people who misunderstand Islam owing to their lack of historical culture (Roy 1990, p. 73). ${ }^{40}$ In some places, important official positions can even be acceded by ill-trained people, such as in Faisalabad (Pakistan) where a qadi (islamic judge) can get his diploma, considered equivalent to a master in law, after a sixweek period (Piquard, p. 73). A military despot, General Zia ul-Haq, conceded to the ulema (in exchange for their support) that the degrees awarded by the madrasas could be recognized as the equivalent of university degrees provided that some portions of the general curriculum were also taught in them (Zaman 2007, p. 78).

We are now ready to address our last question: why have Islamic countries been rather ineffective, historically, in meeting the challenges of modern economic growth and, by way of consequence, in gradually moving toward a more secular approach to social order and the role of individuals in it?

\footnotetext{
${ }^{40}$ The young mollahs have passed sufficient time in the school system to consider themselves as educated persons and to refuse to go back to the land or enter into a factory, yet they have not succeeded in going beyond the secondary school (Roy, p. 73).
} 


\section{Path dependence and the Islamic 'institutional complex'}

\subsection{Statement of the problem}

Part of the answer to the above questions has already been suggested earlier. Emphasis was laid on the cost of reforming societies in which religion can be easily manipulated by political rulers and their contenders. Moreover, as attested by the historical experience of Iran, middle class people may choose to ally themselves with religious leaders in order to achieve better protection against the predations of greedy state officials and the unfavourable policies of an incompetent and corrupt state. In these conditions, it is difficult for progressive elements of society to call for reforms that religious authorities could consider impious or to resort to secular concepts and language in support of the desired changes. What needs to be added now in light of the work of Kuran is that the legacy of the classical Islamic system may have given rise to an "institutional trap", impeding both economic development and the rise of civil society.

\subsection{The institutional trap inherited from the classical Islamic system}

According to Kuran, a direct consequence of the historical context in which Islam was born is that the Qur'an contains rules prescribing the rightful behaviour to follow in a number of civil matters (see above, Section 2). In these matters that it addresses explicitly, the Qur'an carries an especially strong authority, a feature that is absent from Christianity, whose sacred texts are framed in general and allegorical terms. Kuran focuses attention on a number of central institutions born of the classical Islamic system (whether based on the Qur'an or not) ${ }^{41}$ that had the effect of blocking critical institutional changes, including in modern Turkey: the

\footnotetext{
${ }^{41}$ As noted by Kuran, the central economic institutions of the Middle East evolved over the three centuries following the 'age of felicity' (the period of Muhammad and his first four successors). They were firmly in place around 1000 and were to persist up to the $19^{\text {th }}$ century (Kuran 2004b, p. 72).
} 
Islamic law of commercial partnerships, which limited enterprise continuity and intergenerational persistence; the Islamic inheritance system, which encouraged wealth fragmentation and restrained capital accumulation by creating incentives for keeping partnerships small; the waqf system, which inhibited resource pooling; and Islam's traditional aversion to the concept of legal personhood, which hampered the emergence of private corporate organizations (Kuran 1997, 1998, 2001, 2003, 2004a, 2004b, 2004d, 2005, and 2006). Critical among these institutions is the inheritance system (actually based on the Qur'an), which actually prevented the Islamic contract law to evolve as it has done in Western Europe where people found it relatively easy to modify inheritance practices in response to changing needs (since the Bible did not prescribe rules for transferring wealth across generations).

As a result, a whole series of organizational changes that proved essential for the development of a modern economy did not arise in the Muslim lands. The fact that from the late $18^{\text {th }}$ century onward, the indigenous Christians and Jews came increasingly to dominate the most lucrative sectors of the Middle Eastern economy bears witness to the adverse role of Islamic institutions since, unlike the Muslims, members of these minorities were free to choose their law system (Kuran 2004c, Goffman 2002, p. 73). At the start of the $20^{\text {th }}$ century, as a result, almost all large commercial enterprises in the Middle East were owned by either foreigners or local religious minorities (Kuran 2004b, pp. 72 and 84-87, 2004c, Issawi 1971, pp. 67-69). The example of Turkey is particularly interesting because the Islamic law was abrogated there when the Young Turks seized power from the Ottomans and accelerated the country's move along the Westernizing secular path. It thus shows that the lingering effect of erstwhile Islamic institutions inspired by the shari'a rather than the Islamic law itself may be the real stumbling block on the way to modern economic growth. In this way, institutions that were adapted to the ruling economic conditions at the time of their emergence have proven a 
barrier at a more advanced stage of economic development, when Western societies had undergone basic transformations (Jones 1981, Landes 1998, Kuran 2004b, Greif 2006).

Recently, Ghislaine Lydon has lent further support to Kuran's thesis by arguing that a basic flaw in Islamic legal systems is their failure to invest paperwork with legal personality. Paradoxically, while Qur'anic verses placed great emphasis on the importance of writing and documenting credit transactions, written documents such as debt contracts and even fatwas had no value in and of themselves and could not therefore be used as legal evidence in a court of law. This lack of faith in paper stemmed from the belief that documents can easily be tampered with or simply forged, whereas oral testimonies given under an oath by witnesses are quite reliable. This limitation constituted a serious obstacle to the modern development of Muslim economies because it inhibited the growth of 'paper companies', such as joint-stock companies or corporations as well as the development of complex and large-scale enterprise in commerce, industry, and the key sector of banking. ${ }^{42}$

In contrast to the above, Maxime Rodinson (1966, p. 193) contends that Islamic rulings, such as fatwas, "represented a formality that was obtained without difficulty from accommodating theologians, in order to put in the clear religious opinion leaders who had already decided to adopt a certain measure for reasons that were strictly economic and political". He delves extensively into the case of the interest rate and argues that Islamic

\footnotetext{
${ }^{42}$ In another recent paper, Hania Abou al-Shamat (2007) examines the effects in Egypt of the legal reforms of 1883 that established native courts based on the Napoleon code of law to deal with civil, commercial and penal disputes. All Egyptians, regardless of religion, had equal access to and representation in the courts, and documentation requirements were incorporated into the system (written documents could be used as evidence in legal proceedings). The author finds that it is only more than a third of a century after the legal changes were made that national business interests responded to them by creating large enterprises and increasing investment in the industrial and banking sectors. She mentions a number of reasons for this delayed response, including poor enforcement of the new laws by the native courts, the shortage of qualified Egyptian judges and lawyers to serve in them, low trust of Egyptians in the mixed courts competent to deal with cases involving both indigenous and foreign interests, and unfair competition from foreign countries (under the capitulations, foreigners enjoyed lower tariffs and exemption from taxes). She concludes, rather sensibly, that reform in law is a necessary but not sufficient condition for the emergence of new business forms and increased investment in Muslim countries.
} 
prohibitions in this matter have always been circumvented: interest was usually charged under forms considered legitimate, such as commissions or salaries (pp. 179-200). If the argument is historically correct, the example is ill-chosen because Islamic law does not prescribe a penalty for dealing in interest and because, as pointed out by Rodinson himself, it aims at curbing excessive interest rates rather than prohibiting the practice altogether (p. 189). In fact, the claim that Islam categorically prohibits all interest, regardless of form, purpose, or magnitude, on the grounds that it violates a sacred Islamic command has encountered strong resistance from the earliest days of Islam, and in all large communities Muslims have never stopped dealing in interest. ${ }^{43}$ In this, they were aided by the jurists of Islam who devised, as in European territories under Christian rule, stratagems that allowed people to circumvent Islam's presumed interest ban without violating its letter (Kuran 2004b, p. 73). ${ }^{44}$

A number of important implications can be drawn from Kuran's analysis. First, reforming key institutions appears especially difficult in the lands of Islam because they are part of a legacy anchored in sacred texts or in the sacralized period of the caliphate. The only way to modify or replace these institutions is to propose a new interpretation of the Islamic law, which would require quite a strong authority. Such a move has actually taken place in a few countries recently, yet interestingly, it was initiated by an enlightened despot in the absence of real pressures from the civil society. In Morocco and Tunisia, autocratic rulers have, indeed, succeeded in holding traditionalist religious forces in check and enacting

\footnotetext{
${ }^{43}$ In Iran, for instance, around 1850 interest rates averaged 12.50 percent but could vary between 18 30 percent when money became scarce (Issawi). Under the Safavids, the ulemas themselves developed various subterfuges to make commercial habits compatible with Islamic precepts, particularly in the matter of interest rates (Floor, 2000).

${ }^{44}$ Revealingly, it is only with the present-day radicalization of Islam that we observe an energetic campaign against conventional banking in countries formally committed to Islamization (Kuran 2004a, p. 122). In these countries, indeed, Islamic banks have emerged through efforts aiming at differentiating the 'Islamic way of life' from other lifestyles, particularly from those identified with the West. Muslim piety is thus increasingly regarded as involving the shunning of interest. It bears noting that, in countries where Islamic banks coexist with conventional banks and where people have the freedom to choose between them, only a minority of the Muslim population maintains accounts at Islamic banks: the market share of the latter is a tiny 1\% (Kuran 2004a, p. 123; see also Rahnema and Nomani 1990, Kuran 1998, Tripp 2006).
} 
progressive legislations dealing with personal and family matters. The case of Tunisia is particularly interesting because the new code of personal statute, enacted immediately after national independence (in August 1956), is remarkably progressive (e.g., the practices of polygamy and repudiation are forbidden). ${ }^{45}$ It was essentially the work of President Bourguiba, who was eager to legitimize his project of social and political reforms by referring to a modernized version of the discourse of Islam, stressing the need for a new ijtihad and the role of reason in interpreting Islamic laws and prescriptions ${ }^{46}$. According to him, indeed, the main cause of the backwardness of the Muslims during centuries of protracted decadence lay in their refusal to accept the necessity of Reason and in their imprisonment in tradition and imitation (Camau and Geisser 2004).

Second, we have already noted that in some countries a reform movement is hampered by a strong tradition of cooperation between middle class people (including merchants and businessmen) and religious scholars against the arbitrary rule of corrupt state officials. The absence of key reforms then appears as the price that those people are willing to pay in order not to antagonize key allies in their struggle against tyranny. What must be added now is that, even when there is no such strong alliance, a civil society able to push reforms and confront the state is hard to come by for reasons that have again to do with the legacy of traditional Islamic law. According to Kuran, there are two main channels through which Islam exerted its adverse influence on political freedom. For one thing, because the institution of the waqf benefited the economic elite (since they could thereby protect their wealth), it discouraged them from demanding the constitutional enforcement of private property rights. ${ }^{47}$ For another

\footnotetext{
45 The same cannot be said about the 1984 family code of Algeria, which appears to uphold the traditional view of women within society and the family (Mitchell 1997).

${ }^{46}$ The concept of ijtihad points to the process through which a jurist apprehends God's law and can turn it into a legal ruling.

${ }^{47}$ According to Kuran, the institution of the waqf itself was conceived as a device to shelter personal assets and enhance the material security of the high officials; it actually represented "an implicit bargain between rulers and their wealthy subjects" (Kuran 2006, pp. 799-802).
} 
thing, by preventing the emergence of large commercial enterprises, Islam made potential opposition to autocratic rule more fragmented and less effective (Kuran 2004b, pp. 80-83, and 2006, pp. 819-23). It is, therefore, no coincidence that the first parliament of the Middle East (the Ottoman parliament in Istanbul) was established only in 1876 and under Western influences (Kuran 2004b, pp. 82, 87).

Third, because economic and political reforms did not occur owing to the peculiar legacy of Islam, modern values and ideas of the kind propounded by the European Enlightenment could not take strong roots in most of the lands of Islam (with the exception of Turkey). True, by emphasizing the possibility of attaining the truth through the use of human reason as well as the need for liberty in the interpretation of the shari'a ${ }^{48}$, a number of thinkers and philosophers of Islam undoubtedly strode toward a kind of European Enlightenment; think of Roumi and Yünüs Emre (the Sufist Spinoza) in Turkey, Avicenna (Ibn Sina) and Sorawardi in Persia, or (Ibn Rushd) Averroes in Andalus. However, even among progressive philosophers, the ultimate reference to God and the divine world has never been abandoned, ${ }^{49}$ and in any event, the momentum that they initiated was not strong enough to alter in a durable manner the traditionalist perceptions about the role of religion in social and political life. ${ }^{50}$

\subsection{A qualifying remark}

\footnotetext{
${ }^{48}$ Averroes thus believed that not all the words of the Qur'an should be taken literally: "When the literal meaning of Qur'anic verses appeared to contradict the truths to which philosophers arrived by the exercise of reason, those verses needed to be interpreted metaphorically" (Hourani, p. 175).

${ }^{49}$ For Averroes, for example, if there is no incompatibility between faith and human reason since the latter remains inspired by God.

${ }^{50}$ The persisting need to refer to God in the Islamic world is apparent not only in the writings of progressive philosophers, but also in those of economic thinkers. For example, 'authentic' economic Shi'ite writers maintain that private ownership of the means of production is respectable, that rent and profit are legitimate pursuits, that trade and commerce are to be encouraged, and that the market is "the basic economic institution for the provision of the needs of the Islamic community". However, their vision is that of a religious system the objective of which is "to serve God on earth". Therefore, the above-mentioned institutions and processes "must be structured according to and operate within the framework of the Shari' a" (Rahmena and Nomani 1990, p. 160; see also Haenni 2005).
} 
Kuran has stressed that it is only a few, but admittedly critical institutional legacies of the classical Islamic system that are problematic for modern economic growth. In many matters, especially in economic matters, the Islamic principles, whether contained in the Qur'an or in the Hadith, are stated so vaguely or so ambiguously that they can be interpreted in many diverse ways (Kuran 2004d). In matters of inheritance, however, the statements are extremely precise (see Sura IV “About women", verses 7-176), and this inflexibility has caused Islamic contract law to freeze. It must now be pointed out that, even in these matters, the manner in which the Islamic law is interpreted and enforced depends to a large extent upon the prevailing configuration of social and political forces, including the degree to which a society has absorbed Islamic tenets and the context of historical constraints and opportunities.

Thus, in old Islamized communities of rural West Africa and some regions of the Maghreb (e.g., in Kabylia, Algeria, or among the Berbers in Morocco), it is the erstwhile custom rather than the Islamic inheritance law that tends to be enforced. In the Juula and Hausa lands, clerical specialists did not always demand strict religious adherence on the part of the local lay Muslim community. In particular, descent rules could be manipulated to avoid dispersion of business assets by selecting one unique successor among slaves/clients (rather than relatives) recruited into the trading organization as junior partners. In fact, specific arrangements "depended almost entirely upon arrangements made within a modified version of the secular kinship idiom" (Austen 1987, pp. 43-44). The major social function of Islam, in these territories, was "to provide merchants with an identity which reinforced their occupational role", allowing them to act as "representatives of a cult that had material and 
spiritual connections to a universe larger than the parochial world of local villages, or even savanna empires" (Austen, pp. 42-43). ${ }^{51}$

In northern Senegal, Islamization dates back to the colonisation of the (middle) valley of the Senegal river by successive waves of foreign conquerors since the $10^{\text {th }}$ century, and maraboutic power used the 1776 revolution to assert itself and establish the Almaami regime based on the Islamic law (Minvielle 1977). My own field investigations in the area showed that the Qur'anic prescriptions regarding inheritance are well-known by local rural inhabitants who often refer to them as the rules governing the behaviour of Muslims. When their actual behaviour of rule-breaking is pointed out to them (since they tend to follow the custom according to which women do not inherit land), they feel somewhat embarrassed. They are keen to remark that (i) nothing prevents a woman from calling the local marabout and requiring the enforcement of the Islamic norm, and (ii) daughters often receive some sort of compensation from their brothers (e.g., under the form of harvest shares). ${ }^{52}$

In general, it can be confidently asserted that the Islam of the villages is rather flexible compared to the more tightly controlled Islam of the cities. It is actually in cities that puritanical expressions such as found in Islamist movements have been born, and it is in cities (and in rural areas nearby) that strict interpretations of Islam hold sway. Since modern economic growth is typically anchored in urban environments, the institutional flexibility of "village Islam" is of not much help when the problem is to develop sophisticated forms of economic organizations.

It is true that, even in cities, Islamic rulings can be circumvented, yet there are costs involved, and those costs are higher if a puritanical atmosphere prevails. Changes in

\footnotetext{
${ }^{51}$ In the words of Aboubacar Fofana, an influential reformist Muslim cleric of Côte d'Ivoire, "what matters is not where an individual comes from, but what he or she does". Muslim brotherhoods put emphasis on personal merits and engagement, not on social status and ethnic identity: they are based on elective membership (Miran, pp. 450, 472-73).

${ }^{52}$ For a similar observation in Niger, see Cooper (1997), and see Bedoucha (1987) for another illustration of the flexible interpretation of the Qur'anic inheritance law among the Tuaregs, based on a subtle blending of written tenets, oral tradition and tacit understanding.
} 
institutions may occur through surreptitious modifications, lengthy negotiations and casuistry, legal fictions, exploitation of ambiguities, and corruption of rule enforcers. The Islamic prohibition of innovations (bid'a) offers a good illustration. The systematic prohibition of all techniques and practices differing from those prevailing in the times of the Prophet has been quickly abandoned, and the distinction, introduced in the Middle Ages, between what constitute 'good' and 'bad' innovations was a useful compromise enabling rulers and scholars to escape absurd situations (Rodinson, pp. 180-81). The fact remains, however, that the notion of harmful innovations has persisted and can be potentially used by conservative ulema to block useful changes or increase their cost. For instance, upon the request of Abdul Aziz, king of Saudi Arabia, ulema close to him had to exert themselves to find in the sacred texts a proper justification for an innovation as fundamental as photography. This innovation was eventually accepted, despite the idolatry of pictorial art, on the ground that it brings together light and shadow, which are both divine creations (Nomani and Rahnema, p. 139). In most other Arab countries where such a puritanical atmosphere did not prevail, the transaction costs involved in constructing a religious justification of photography could be saved. ${ }^{53}$

Furthermore, when changes are brought through essentially illegal practices, pressures for fundamental institutional reform are reduced, and vast constituencies with a vested interest in the status quo are generated (Kuran 2003, pp. 428-31, and 2004b, p. 81). ${ }^{54}$ Thus, centuries of efforts to overcome the inflexibility of institutions such as the waqf system have bred a

\footnotetext{
${ }^{53}$ Another interesting illustration of both the ingenuity of the jurists in adapting the Islamic law (in this case, the absence of recognition of human groups as legal entities and the Hanafi law of inheritance; inheritance is not confined to direct descendants, and each heir has a canonical right to a fixed share of the deceased's property) and the ultimate constraints set by it has been provided by Kermeli (1997) while dealing with the treatment meted out to church waqfs under the Ottoman empire. By re-defining the monks of a monastery as a family, Ebu's Su'ud (who became seyhulislam in 1545) recognized their collectivity and enabled them to receive the property belonging to a deceased monk (since they were considered as his offspring). However, he ordered them to make waqfs in their own names, not in the name of the monastery since monastic waqfs were not permitted in Islamic law. Realizing the pitfalls of this legal fiction used for the benefit of the monks of Mount Athos, Ebu's Su'ud quickly issued a fatwa restricting similar claims from other monasteries.

${ }^{54}$ In the words of Kuran, "to identify opportunities for circumventing a law is not to establish that law's irrelevance or to prove that the opportunities were available to everyone" (2003, p. 430).
} 
culture of corruption and nepotism in state circles. This, in conjunction with the deep-rooted habit of personalizing exchanges and attributing responsibility for an adverse externality to a natural person or group rather than to a legal person, makes the establishment of the rule of law the hard challenge that it is in the Middle East today (Kuran 2004b, pp. 86-87).

\section{Conclusion}

In the light of historical evidence, it is hard to claim that politics and Islam have been systematically merged together or that politics has been the handmaiden of Islam. In ordinary times, even after the legal community of Islamic scholars (judges, teachers, legal advisers and jurisconsults) had been set firmly in place during the early Abbasids, political rulers have had the upper hand, much as in Western European history. Religious authorities and groups typically played the role of a buffer between the state and the people, often providing shelter against the ruler's abuses and acting as a mediator to encourage negotiation with political opponents. In times of crisis, however, when the state was either impotent or excessively tyrannical, such politico-religious equilibrium was broken and religion gained greater significance. In addition, the growing role of religion could also be the result of a strategy of political instrumentalization whereby the political ruler used his Islamic credentials to tame opposition and crush dissent.

Lewis thus appears to have the wrong diagnosis when he contends that the root cause of the existence of illiberal regimes in Middle Eastern countries lies in politics being the handmaiden of Islam when the opposite appears to be much closer to the truth. Moreover, he does not explain satisfactorily (unless one is convinced by his argument about the critical moment of the foundation of the faith) why the separation between state and religion has not occurred some time in its history, as has happened in Western Europe. This lapse is not 
coincidental since Lewis is convinced that the merging of state and religion is an intrinsic feature of Islam; that is, a situation that cannot be remedied.

According to Timur Kuran and Avner Greif, a critical obstacle to essential economic and political reforms and, it can be added, to changes in ideas and values that would justify the need for an autonomous sphere of economic activity unimpeded by political and religious restrictions, lies in some elements of the 'institutional complex' inherited from the classical system of Islam. They have caused the emergence of institutional traps at the time when Western Europe was making rapid and sustained advances on the basis of critical institutional innovations. A legacy of the Islamic civilization, which was well suited for progress until the advent of modern times, thus came to hamper economic achievements rivalling those of Western Europe.

If we follow such a dynamic approach to the present crisis of Islamic societies, we have to admit that culture in general, and religion in particular, can be an impediment to progress. By way of consequence, stressing that religion is often instrumentalized by key political players does not imply that it may not hinder the modernization of a country; there is, indeed, a core institutional legacy of Islam that sets an ultimate set of constraints upon the range of feasible policies and reforms. Maxime Rodinson and Fareed Zakaria have argued that religion, because it is easily manipulated by political actors, does not constitute an autonomous force that is, by itself, susceptible of promoting or retarding economic growth and development. As a result, the notion that "the key is not religious reform, but political and economic reform...if you get the politics and economics right, culture will follow" (Zakaria, p. 150) is too simple.

Even if one disagrees with the theory of the "institutional trap" propounded by Kuran (and Greif), there remains the fact that, in Islam, no clear chain of command exists that is able to enforce a strict, uniform interpretation of the message of the faith. The consequence of this 
situation is that socio-religious movements eager to block progress toward individual emancipation have numerous possibilities open to them and elites are provided with a rather cheap default option whereby they can escape the effects of their misrule and suppress political opposition. A nasty obscurantist deadlock may thus be created in which puritanical interpretations of Islam, claiming that the letter rather than the spirit of the Qur'an must be followed, as well as mythical appraisals of early achievements of the Islamic civilization emerge and gain ground.

The central question then arises as to how politics can be made right in such conditions. In particular, given the high costs and risks of undertaking reforms necessary for effective competition with advanced countries in the modern age, how can more democratic institutions be established, and how can political integration be achieved without reference to Islam? The task is all the more daunting as international events have considerably increased the temptation to instrumentalize Islam for rulers who have suffered a series of humiliating defeats or setbacks at the hands of advanced countries that often had a poor understanding of and paid insufficient attention to Arab interests and problems. Had the Western powers taken a more enlightened route earlier in dealing with the Palestinian question, perhaps the nascent Arab secular movements in the fifties and the sixties would have been given a better opportunity to take roots. Given such highly explosive circumstances prevailing in the Middle East today, it is perhaps not coincidental that enlightened despots (such as Ataturk or Bourguiba), determined to embark upon a new interpretation of the Islamic law that would leave ample room for the role of reason, might appear as holding the best prospects for breaking out of the obscurantist deadlock. If such an implication is correct, those advanced countries that proclaim their willingness to promote democracy in this part of the world are confronted with a strange paradox over which they should ponder. 
There are obviously complex interactions and feedback effects between culture and institutional change that are too much ignored by both Lewis and Zakaria. When they are taken into account, a basic contrast emerges between the virtuous development trajectory of Western Europe in modern times and the vicious path trodden by Islamic countries. Whereas in the former countries institutional and ideological changes have reinforced each other in a beneficial manner, deriving much of their strength from more or less continuous improvements in living standards, in the latter economic performances and social progress have remained hampered by a long tradition of despotism and insufficient competitiveness with the advanced part of the Western world, coupled with an adverse international environment tainted by a vicious regional conflict at the heart of the Middle East. 


\section{References}

Abrahamian, E., 1982. Iran Between Two Revolutions. Princeton: Princeton University Press.

Adelkhah, F., 1991. La révolution sous le voile. Paris: Karthala.

Adler, A., 2005. Rendez-vous avec l'Islam, Paris : Grasset.

Acemoglu, D., Robinson, J.A., 2006. Economic Origins of Dictatorship and Democracy. Cambridge: Cambridge University Press.

Algar, H., 1969. Religion and State in Iran, 1785-1906. The Role of the Ulama in the Qajar Period. Berkeley: University of California Press.

Al-Banna, H., 1996. The Message of the Teachings. London: International Islamic Forum.

Al-Rasheed, M., 1996. God, the king and the nation: Political rhetoric in Saudi Arabia in the 1900s. The Middle East Journal 50, 359-371.

Al-Rasheed, M., 2002. A History of Saudi Arabia. Cambridge: Cambridge University Press.

Al-Rasheed, M., 2006. Contesting the Saudi State: Islamic Voices from a New Generation. Cambridge: Cambridge University Press.

Al-Shamat, H.A., 2007. The effect of legal reform on Muslims' commercial and financial performance in Egypt, 1883-1920. Paper presented to the $11^{\text {th }}$ annual conference of the International Society for New Institutional Economics, Reykyavik, June 21-23.

Anderson, M.S., 2003. The Ascendancy of Europe 1815-1914. Harlow, Essex: Pearson Longman.

Aquil, F., 2006. Etude sur l'identification de l'état des connaissances du Code de la Famille par les bénéficiaires du micro-crédit au Maroc. Maroc: Planète Finance.

Arjomand, S., 1984. The Shadow of God and the Hidden Imam. Chicago: University of Chicago Press.

Armstrong, K., 2001. Islam. A Short History. London: Phoenix Press.

Austen R., 1987. African Economic History. London and Portsmouth: James Currey and Heinemann.

Avineri, S., 1968. The Social and Political Thought of Karl Marx. Cambridge: Cambridge University Press.

Barro, R.J., McCleary, R.M., 2003. Religion and economic growth across countries. American Sociological Review 68, 760-781. 
Bates, R.H., 2001. Prosperity and Violence. New York: W.W. Norton \& Cy,.

Bedoucha, G., 1987. Transmission des patrimoines en terroir oasien. Idéal lignager et pratiques sociales à El Mansoura (Tunisie). In : Gast, M. (Ed.). Hériter en pays musulman. Habus, lait vivant, Manyahuli. Paris : Editions du CNRS (Centre National de la Recherche Scientifique), pp. 75-89

Berkey, J.P., 1992. The Transmission of Knowledge in Medieval Cairo: A Social History of Islamic Education. Princeton: Princeton University Press,.

Berkey, J.P., 2007. Madrasas medieval and modern: politics, education, and the problem of Muslim identity. In: Hefner, R.W., Zaman, M.Q. (Eds.). Schooling in Islam. The Culture and Politics of Modern Muslim Education. Princeton: Princeton University Press, 40-60.

Boone, C., 1992. Merchant Capital and the Roots of State Power in Senegal 1930-1985. Cambridge: Cambridge University Press.

Bouamama, S., 2000. Algérie: Les racines de l'intégrisme. Bruxelles: Editions EPO.

Boubekeur, A., 2004. Nouvelles stratégies matrimoniales d'étudiantes voilées en France. In: Taboada Leonetti, I. (Ed.). Les femmes et l'Islam -Entre modernité et intégrisme. Paris: L'Harmattan, 145-154.

Braudel, F., 1995. A History of Civilizations. London: Penguin Books.

Briggs, R., 1999. Embattled faiths: religion and natural philosophy in the seventeenth century. In: Cameron, E. (Ed.). Early Modern Europe: An Oxford History. Oxford: Oxford University Press, 171-205.

Camau, M., Geisser, V., 2004. Habib Bourguiba: la trace et l'héritage. Paris: Karthala.

Cleveland, W.L., 2004. A History of the Modern Middle East. Oxford: Westview Press.

Collins, J.B., Taylor, K.L., 2006. Early Modern Europe: Issues and Interpretations. Oxford: Blackwell Publishing.

Cooper, B.M., 1997. Marriage in Maradi: Gender and culture in a Hausa society in Niger, 1900-1989. Oxford: James Currey.

Cosgel, M., Ahmed, R., Miceli, T., 2007. Law and state power: The institutional roots of the strong state in Islamic history. Paper presented to the conference 'The economic performance of civilizations: roles of culture, religion, and the law', University of Southern California, Institute for Economic Research on Civilizations, Los Angeles, February 23-24.

Cruise O'Brien, D.B., 1971. The Mourides of Senegal: Political and Economic Organisation of an Islamic Brotherhood. Oxford: Oxford University Press. 
Cruise O'Brien, D.B., 1975. Saints and Politicians: Essays in the Organisation of a Senegalese Peasant Society. Cambridge: Cambridge University Press.

Davidson, B., 1991. Africa in History. New York: Simon and Schuster (Touchstone Book).

Dawisha, A., 1999. Identity and political survival in Saddam's Iraq. The Middle East Journal $53,553-567$.

Dawisha, A., 2003. Arab Nationalism in the Twentieth Century: From Triumph to Despair. Princeton: Princeton University Press.

De Waal, A., 1997. Famine Crimes: Politics and the Disaster Relief Industry in Africa. Oxford: James Currey.

Economist, 2006a. Sunnis and Shias. Special Report, March 4-10, p. 22.

Economist, 2006b. Putting the malaise into Malaysia. November 30-December 2, pp. 57-58.

El Badawi, I., Makdisi, S., 2007. Explaining the democracy deficit in the Arab world. The Quarterly Review of Economics and Finance 46, 813-831.

El Mansour, M., 1979. The Sanctuary (hurm) in Precolonial Morocco. In: Bourqia, R., Gilson Miller, S. (Eds.). In the Shadow of the Sultan: Culture, Power, and Politics in Morocco. Cambridge, MA: Harvard University Press, 49-73.

Fage, J.D., Tordoff, W., 1995. A History of Africa. London and New York: Routledge.

Ferjani, M.C., 1991. Islamisme, laïcité, et droits de l'homme. Paris: L'Harmattan.

Fish, S., 2002. Islam and authoritarianism. World Politics 55, 4-37.

Floor, W., 1980. The revolutionary character of the Iranian Ulama: Wishful thinking or reality? International Journal of Middle East Studies 12, 501-524.

Floor, W., 2000. The Economy of Safavid Persia. Wiesbaden: Reichert.

Gleave, R., (Ed.), 2005. Religion and Society in Qajar Iran. New York: Routledge Curzon.

Gleave, R., Kermeli, E. (Eds.), 1997. Islamic Law. Theory and Practice. London and New York: I.B. Tauris Publishers.

Goffman, D., 2002. The Ottoman Empire and Early Modern Europe. Cambridge: Cambridge University Press.

Göle, N., 1993. Musulmanes et modernes. Paris: La Découverte. 
Greif, A., 2006. Institutions and the Path to Modern Economy: Lessons from Medieval Trade. Cambridge: Cambridge University Press.

Guiso, L., Sapienza, P., Zingales, L., 2003. People's opium? Religion and economic activities. Journal of Monetary Economics 50, 225-282.

Haenni, P., 2005. L’Islam de marché. Paris: Editions du Seuil.

Harik, J.P., 2005. Hezbollah: The changing face of Terrorism. London and New York: I.B. Tauris Publishers.

Hassan, G.S., Kivimäki, T., 2005. Relations between Islam and the West as a context and catalyst of terrorism. In: Kivimäki, T., (Ed.). Islam, the West, and Violence. Helsinki: Hakapaino Oy, 116-145.

Higgins, B., 1968. Economic Development: Problems, Principles and Policies. New York: W.W. Norton \& Company.

Horowitz, D., 1985. Ethnic Groups in Conflict. Berkeley: University of California Press.

Hourani, A., 1991. A History of the Arab Peoples. Cambridge, MA: The Belknap Press of the Harvard University Press.

Huuhtanen, H., 2005. Weak states and terrorism in the Arab world. In: Kivimäki, T., (Ed.). Islam, the West, and Violence. Helsinki: Hakapaino Oy, 73-89.

Imber, C., 2002. The Ottoman Empire, 1300-1650: The Structure of Power. New York: Palgrave Macmillan.

Inalcik, H., 1973. The Ottoman Empire: The Classical Age, 1300-1600. London: Phoenix Press.

Inalcik, H., Quataert, D., 1994. An Economic and Social history of the Ottoman Empire, 1300-1914. Cambridge and New York: Cambridge University Press,.

Israel, J.I., 2001. Radical Enlightenment: Philosophy and the Making of Modernity 16501750, Oxford: Oxford University Press.

Issawi, C., 1971. The Economic History of Iran, 1800-1914. Chicago: University of Chicago Press.

Janos, A.C., 1982. The Politics of Backwardness in Hungary, 1825-1945. Princeton: Princeton University Press.

Jones, E., 1981. The European Miracle. Cambridge: Cambridge University Press.

Johnson, D.H., 2003. The Root Causes of Sudan’s Civil Wars. Oxford: James Currey.

Kassir, S., 2004. Considérations sur le malheur arabe. Paris: Actes Sud/Sindbad. 
Keddie, N., 1966. Religion and Rebellion in Iran: The Tobacco Protest of 1891-1892. London: Frank Cass.

Keddie, N., 1969. The roots of the Ulama's power in modern Iran. Studia Islamica 29, 31-53.

Keddie, N., 1971. The Iranian power structure and social change, 1800-1969. International Journal of Middle East Studies 2, 3-20.

Keddie, N., 1999. Qajar Iran and the Rise of Reza Khan, 1796-1925. Costa Mesa, CA: Mazda Publishers.

Kermeli, E., 1997. Ebu Su'ud definitions of church waqfs: Theory and practice in Ottoman law. In: Gleave, R., Kermeli, E. (Eds.). Islamic Law. Theory and Practice. London and New York: I.B. Tauris Publishers, 141-156.

Kepel, G., 1994. The Revenge of God: The Resurgence of Islam, Christianity and Judaism in the Modern World. Philadelphia: Pennsylvania University Press.

Koenigsberger, H.G., Mosse, G.L., Bowler, G.Q., 1989. Europe in the Sixteenth Century. Harlow: Longman.

Kuran, T., 1997. Islam and underdevelopment: An old puzzle revisited. Journal of Institutional and Theoretical Economics 153, 41-71.

Kuran, T., 1998. The genesis of Islamic economics: A chapter in the politics of Muslim identity. Social Research 64, 301-338.

Kuran, T., 2001. The provision of public goods under Islamic law: Origins, impact, and limitations of the waqf system. Law \& Society Review 35, 841- 897.

Kuran, T., 2003. The Islamic commercial crisis: Institutional roots of economic underdevelopment in the Middle East. Journal of Economic History 63, 414-446.

Kuran, T., 2004a. Cultural obstacles to economic development: Often overstated, usually transitory. In: Rao, V., Walton, M. (Eds.). Culture and Public Action. Stanford, CA: Stanford University Press, 115-137.

Kuran, T., 2004b. Why the Middle East is economically underdeveloped: historical mechanisms of institutional stagnation. Journal of Economic Perspectives 18 (3), 71-90.

Kuran, T., 2004c. The economic ascent of the Middle East's religious minorities: The role of Islamic legal pluralism. Journal of Legal Studies 33, 475-515.

Kuran, T., 2004d. Islam and Mammon: The Economic Predicaments of Islamism. Princeton: Princeton University Press.

Kuran, T., 2005. The logic of financial westernization in the Middle East. Journal of Economic Behavior and Organization 56, 593-615. 
Kuran, T., 2006. The absence of the corporation in Islamic law: origins and persistence. The American Journal of Comparative Law 53, 785-834.

Lambton, A., 1988. Qajar Persia: Eleven Studies. Austin: University of Texas Press.

Landes, D., 1998. The Wealth and Poverty of Nations. London: Little, Brown and Cy.

LaPorta, R., Lopez-de-Silanes, F., Shleifer, A., Vishny, R.W., 1997. Trust in large organizations. American Economic Review 87, 333-338.

Layachi, A., 1995. Algeria: reinstating the state or instating a civil society? In: Zartman, I.W.(Ed.). Collapsed States: The Disintegration and Restoration of Legitimate Authority. Boulder and London: Lynne Rienner Publishers, 171-189.

Le Goff, J., 2003. L’Europe est-elle née au Moyen-Âge? Paris: Editions du Seuil.

Lewis, B., 1993. Islam and liberal democracy. Atlantic Monthly 271, 89.

Lewis, B., 1995. The Middle East: 2000 Years of History from the Rise of Christianity to the Present Day. London: Phoenix.

Lewis, B., 2002. What Went Wrong? Western Impact and Middle Eastern Response. London: Phoenix.

Lydon, G., 2007. A 'paper economy of faith' without faith in paper: A contribution to understanding the roots of Islamic institutional stagnation. Paper presented to the conference 'The economic performance of civilizations: roles of culture, religion, and the law', University of Southern California, Institute for Economic Research on Civilizations, Los Angeles, February 23-24.

Makiya, K., 1989. Republic of Fear: The politics of Modern Iraq. Berkeley, Los Angeles and London: University of California Press.

Makdisi, G., 1981. The Rise of Colleges: Institutions of Learning in Islam and the West. Edinburgh: Edinburgh University Press.

Mansfield, P., 2003. A History of the Middle East. London: Penguin Books.

Martin, V., 2005. The Qajar Pact: Bargaining, Protest and the State in Nineteenth-Century Persia. London and New York: I.B. Tauris Publishers.

Matthew, S., 1990. Fishing Legislation and Gear Conflicts in Asian countries. Brussels: Samudra Publications.

Meddeb, A., 2002. La maladie de l'Islam. Paris: Editions du Seuil.

Meddeb, A., 2004. L'intégrisme, maladie de l'Islam. In: Taboada Leonetti, I. (Ed.). Les femmes et l'Islam -Entre modernité et intégrisme. Paris: L'Harmattan, 165-179. 
Meredith, Martin, 2005. The State of Africa: A History of Fifty Years of Independence. London: The Free Press.

Milet, E., 2005. Mali. Genève: Guides Olizane.

Miller, J., 1993. The challenge of radical Islam. Foreign Affairs 72, 43-56.

Minvielle, J.P., 1977. La structure foncière du waalo fuutanké - Les terres inondables de la moyenne vallée du Sénégal, région de Matam. Paris and Dakar: Centre ORSSTOM (Office de la Recherche Scientifique et Technique d'Outre-Mer).

Miran, M., 2006. Islam, histoire et modernité en Côte d'Ivoire. Paris: Karthala.

Mitchell, R., 1997. Family law in Algeria before and after the 1404/1984 family code. In: Gleave, R., Kermeli, E. (Eds.). Islamic Law. Theory and Practice. London and New York: I.B. Tauris Publishers, 194-204.

Nahavandi, F., 1999. L'instrumentalisation de la religion dans les pays musulmans 'convertis'. In: Nahavandi, F., Claeys, P. (Eds.). La question de l'Islam et de l'Etat à l'aube du XXIe siècle. Civilisations 48 (special issue), 85-97.

Naipaul, V.S., 1982. Among the Believers: An Islamic Journey. New York: Vintage Books.

Nevo, J., 1998. Religion and national identity in Saudi Arabia. Middle Eastern Studies 34, 34-53.

Noland, M., 2005. Religion and economic performance. World Development 33, 1215-1232.

Noland, M., 2008. Explaining Middle Eastern Authoritarianism. Review of Middle East Economics and Finance 4 (1), 1-30.

Nomani, F., Rahnema, A., 1994. Islamic Economic Systems. London and New Jersey: Zed Books.

North, D.C., 2005. Understanding the process of economic change. Princeton and Oxford: Princeton University Press.

North, D.C., Weingast, B.R., 1989. Constitutions and commitment: the evolution of institutions governing public choice in seventeenth-century England. The Journal of Economic History 49, 803-832.

Owen, R., 1992. State, Power and Politics in the Making of Modern Middle East. New York: Routledge.

Pettegree, A., 2003. Religion and the revolt. In: Darby, G. (Ed.). The Origins and Development of the Dutch Revolt. London and New York: Routledge, 67-83.

Pipes, R., 1995. Russia under the Old Regime. London: Penguin Books. 
Piquard, B., 1999. Mobilisation politique et mouvements politico-religieux au Pakistan. In: Nahavandi, F., Claeys, P. (Eds.), La question de l'Islam et de l'état à l'aube du XXIe siècle. Civilisations 48 (special issue), 69-83.

Pryor, F., 2007. The economic impact of Islam on developing nations. World Development $35,1815-1835$.

Raeff, M., 1984. Understanding Imperial Russia. New York: Columbia University Press.

Rahnema, A., Nomani, F., 1990. The Secular Miracle: Religion, Politics and Economic Policy in Iran. London: Zed Books.

Riasanovsky, N.V., 1993. A History of Russia (5 $5^{\text {th }}$ ed.). New York and Oxford: Oxford University Press.

Rodinson, M., 1966. Islam et capitalisme. Paris: Editions du Seuil. (English translation: Islam and Capitalism. London: Saqi Essentials, 2007).

Roy, O., 1990. De l'Islam révolutionnaire au néo-fondamentalisme. Revue Esprit, Numéro spécial: Islam: qu'est-ce que le néo-fondamentalisme?, juillet, 5-14.

Roy, O., 2004. Globalized Islam. The Search for a New Ummah. New York: Columbia University Press.

Sala-i-Martin, X., Doppelhofer, G., Miller, R.I., 2004. Determinants of long-run growth: a Bayesian averaging of classical estimates (BACE) approach. American Economic Review 94, 813-835.

Schumpeter, J., 1954. History of Economic Analysis. New York: Oxford University Press.

Shari'ati, A., 1986. What is to be Done: The Enlightened Thinkers and an Islamic Renaissance. Houston: IRIS.

Shaw, S.J., 1976. History of the Ottoman Empire and Modern Turkey, Vol. 1: Empire of the Gazis: The Rise and Decline of the Ottoman Empire 1280-1808, Cambridge: Cambridge University Press.

Strong, R., 2007. A Little History of the English Country Church. New York: Vintage Books.

Tawney, R.H., 1926. Religion and the Rise of Capitalism, A Historical Study. Reprinted 1987 London: Penguin Books.

Tessler, M., 2002. Islam and democracy in the Middle East: The impact of religious orientations on attitudes toward democracy in four Arab countries. Comparative Politics 34, 337-354.

Toynbee, A., 1972. A Study of History. (the one-volume edition). Oxford: Oxford University Press and Thames and Hudson Ltd. 
Tripp, C., 2006. Islam and the Moral Economy: The Challenge of Capitalism. Cambridge: Cambridge University Press.

Walicki, A., 1979. A History of Russian Thought from the Enlightenment to Marxism. Stanford, CA: Stanford University Press.

Weber, M., 1930. The Protestant Ethic and the Spirit of Capitalism. London: Allen and Unwin.

Zakaria, F., 2003. The Future of Freedom. New York and London: W.W. Norton \& Company.

Zaman, M.Q., 2007. Tradition and authority in Deobandi Madrasas of South Asia. In: Hefner, R.W., Zaman, M.Q. (Eds.). Schooling in Islam. The Culture and Politics of Modern Muslim Education. Princeton: Princeton University Press, 61-86. 